\title{
Highly Insulating Windows for Improved Energy Efficiency and Reliability in Fenestration Applications
}

DE-FC26-06NT42765

Final Report for Budget Period 1 and Budget Period 2

June 15, 2006 - December 31, 2010

to

Parrish Galusky

Marc LaFrance

Department of Energy

National Energy Technology Laboratory

Energy Efficient Buildings Technologies

3610 Collins Ferry Road, P.O. Box 880

Morgantown, WV 26507-0880

\author{
by \\ EverSealed Windows, Inc. \\ Technical Contact and PI: David Stark, President \\ 1999 Interlocken Drive \\ Evergreen, CO 80439-8952 \\ TEL: 303-674-1197 \\ FAX: 303-670-1249 \\ Email: David@EverSealedWindows.com
}




\section{DISCLAIMER}

This report was prepared as an account of work sponsored by an agency of the United States Government. Neither the United States Government nor any agency thereof, nor any of their employees, makes any warranty, express or implied, or assumes any legal liability or responsibility for the accuracy, completeness, or usefulness of any information, apparatus, product, or process disclosed, or represents that its use would not infringe privately owned rights. Reference herein to any specific commercial product, process, or service by trade name, trademark, manufacturer, or otherwise does not necessarily constitute or imply its endorsement, recommendation, or favoring by the United States Government or any agency thereof. The views and opinions of authors expressed herein do not necessarily state or reflect those of the United States Government or any agency thereof.

\section{ACKNOWLEDGEMENT STATEMENT}

This report was prepared with the support of the U.S. Department of Energy, under Award No. DE-FC26-04NT42765. However, any opinions, findings, conclusions, or recommendations expressed herein are those of the author(s) and do not necessarily reflect the views of the DOE.

\section{SUBMITTED TO:}

Parrish Galusky, Project Manager

U.S. Department of Energy, National Energy Technology Laboratory

3610 Collins Ferry Road, P.O. Box 880 [MS-E06]

Morgantown, WV 26507-0880

Phone: 304/285-4358, Parrish.Galusky@netl.doe.gov

\section{SUBMITTED BY:}

EverSealed Windows, Inc.

1999 Interlocken Drive, Evergreen, CO 80439-8952

Phone: 303/674-1197, Fax: 303/670-1249

Project Director:

Mr. David Stark, Phone: 303/674-1197, David@EverSealedWindows.com 


\section{Highly Insulating Windows for Improved Energy Efficiency and Reliability in Fenestration Applications \\ DE-FC26-06NT42765 \\ Progress Report (Final Report) for Budget Period 1 (BP-1) and Budget Period 2 (BP-2)}

March 7, 2011

\section{Table of Contents}

\section{Budget Period \# 1}

Page

1 Summary of BP1 Project Goals Accomplished or Missed .................................. 5

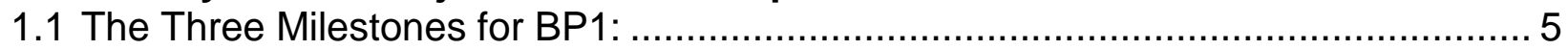

2 Discussion - Activities, Accomplishments, Key Results ..................................... 7

2.1 Milestone 30: Determine and Document Test Success/Failure Criteria for TV3's ...... 7

2.2 Milestone 31: Design and Test of the Metal Bellows to Prove Long-Term

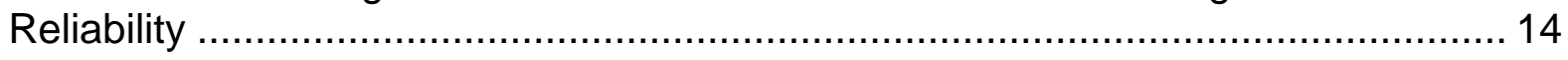

2.3Milestone 32: Production Cost Prediction ..................................................... 17

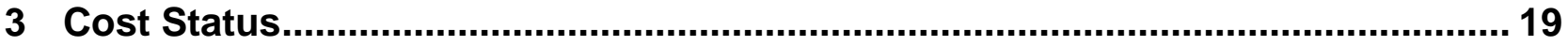

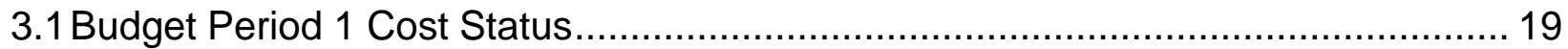

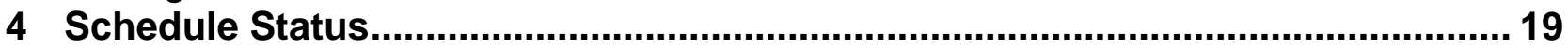

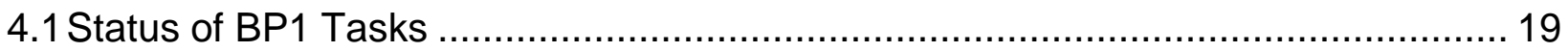

4.2The Negotiated Work Breakdown Structure (WBS) or Work Plan for the Three

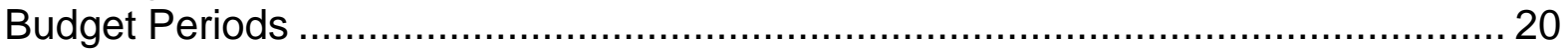

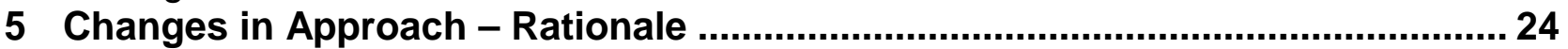

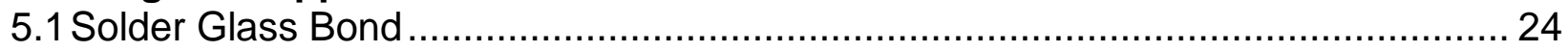

5.2 Industry Collaboration on Success/Failure Criteria: Project's Task 30 .................... 24

6 Actual or Anticipated BP1 Problems or Delays ................................................. 25

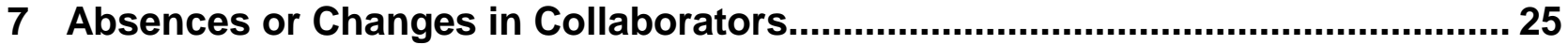

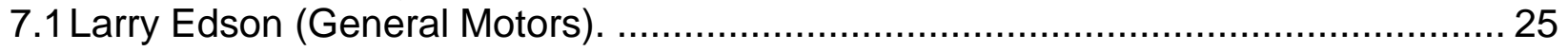

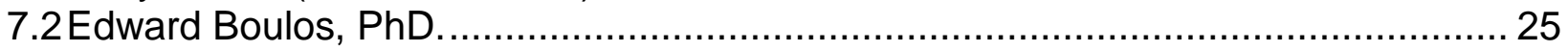

8 Product Produced or Technology Transfer Activities Accomplished During

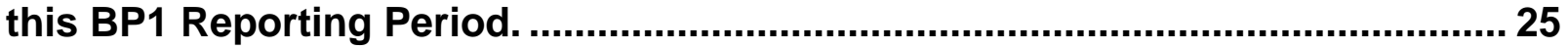




\section{Budget Period \# 2}

Page

9 Summary of BP2 Project Goals Accomplished or Missed .................................. 27

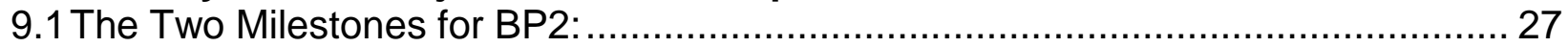

10 Discussion - Activities, Accomplishments, Key Results of BP2 ....................... 28

10.1 TV-1, Tasks 4 through 10: Develop the best material match of metal to sodalime float glass; develop and demonstrate and test the mechanical strength of glass-to-metal bonds

10.2 TV-2, Tasks 13 through 16: Design, assemble and test parts to determine the hermeticity of EverSealed Windows' glass-to-metal bonds................................. 32

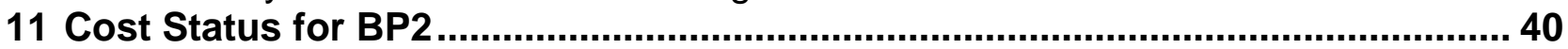

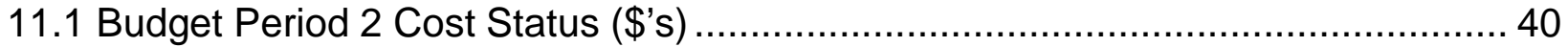

12 Actual or Anticipated Problems or Delays ........................................................ 40

12.1 Use of Stainless Steel Metals and Their Unacceptable CTE Mis-Match To

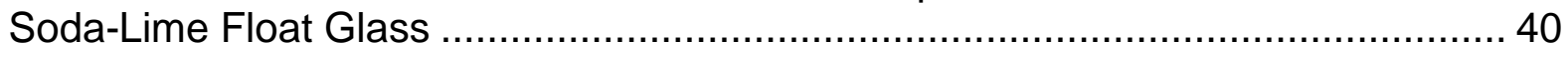

12.2 Conversion to a Non-Stainless Steel Metal Alloy ............................................. 41

12.3 Conversion to a Solder-Glass Bond ............................................................ 41

13 Product Produced or Technology Transfer Activities Accomplished During this BP2 Reporting Period. ............................................................................... 41

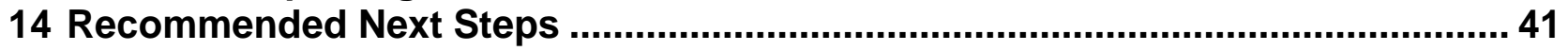

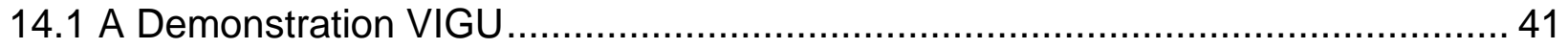

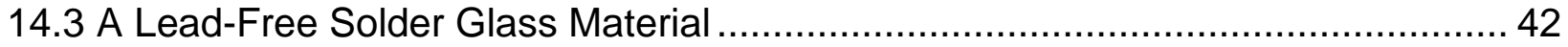




\section{Budget Period \# 1}

\section{Summary of Project Goals Accomplished or Missed}

\subsection{The Three Milestones for BP1:}

ESW agreed in early 2006, prior to the contract award, to add three additional deliverables to the Project (new Milestones 30, 31 and 32), and have the results of these three deliverables form the basis of the go/no-go decision for proceeding from BP1 to BP2. ESW completed all three milestones and the DOE agreed in November 2006 to continue the Project. ESW subsequently initiated work on BP2 and its two milestones. These were to 1) Assemble and test glass-to-metal bonded coupons to test the strength of ESW's glass-to-metal bonds (ESW's Test Vehicle 1 or TV1), and 2) to assemble and test the hermeticity of glass and metal packages (ESW's Test Vehicle 2 or TV2). ESW completed both milestones of BP2 in late 2010, demonstrating that its bonds were both strong enough and hermetic enough that vacuum insulating glass units could be assembled and survive a $40+$ year service life in any climate in North America.

\subsubsection{Milestone 30: Determine and Document Test Success/Failure Criteria for EverSealed Windows' Test Vehicle 3 (TV3)}

ESW, together with its Industry Collaborators, compiled the Test and Validation (T\&V) plan for the Test Vehicle \#3 (TV3) prototypes. See http://www.eversealedwindows.com/allstarteam.html for a list of the industry and DOE laboratory collaborators. The DOE expectation was that ESW would put together a T\&V plan that would receive subsequent review by the DOE and appropriate organizations of its choosing to determine the relevancy and acceptability of the plan by the window and door industry. ESW took the unusual but efficient path of creating the T\&V Plan with the industry as a collaborator in the effort. Inputs to this plan came from the following ESW collaborators:

- Two (2) Float Glass producers.

- Two of the largest soda-lime float-glass producers in the U.S.

- Two (2) Residential window and door manufacturers.

- Two of the largest residential window and door producers in the U.S.

- One (1) Commercial window and door manufacturer.

- The U.S. manufacturing subsidiary of the world's largest skylight producer.

ESW also brought on board Larry Edson as a consultant. Larry is a Senior Technical Fellow at General Motors (GM), with responsibilities for reliability, 
world-wide. For the bulk of the past 37 years he has been developing and implementing accelerated life testing techniques to rapidly characterize and improve reliability for all mechanical and electrical component types in GM's vehicles.

ESW reviewed the T\&V Plan and received industry consensus for this BP1 version at ESW's Team Meeting on November 8-9, 2006 in Lakewood, Colorado. This document is referred to as the BP1 version because ESW considers it important that this be a living document and subject to later changes if they are deemed appropriate.

\subsubsection{Milestone 31: Design And Test Of The Metal Bellows To Prove Long-Term Reliability}

This DOE assignment tasked ESW to:

- Determine and document the requirements for the bellows: size, thickness, operating environmental conditions.

- Design the bellows, perform Finite Element Analysis (FEA) and other simulations, and iterate the design until the bellow performs as required

- Document results in a task report

The confidential task report, previously submitted to the DOE EERE and DOE NETL, documents the procedures used to determine the materials appropriate for the bellows, the methodologies used to design the bellows, and describes the FEA methodology and results that validated the ability of the bellows to perform as required for the TV3 vacuum insulating glass unit to operate reliably for its intended lifetime.

\subsubsection{Milestone 32: Production Cost Prediction}

The DOE requested ESW to develop a cost model for the production of an eventual vacuum insulating glass unit (VIGU or VIG). The DOE wanted to know this information because of the possible consumer cost sensitivity to choosing this VIG over today's gas-filled IG. ESW developed the production cost model, which shows the greatest sensitivity to production cost is the choice of metal for the bellows.

Using what ESW believes to be the best candidate material at this time, with a daily production output of 900 VIGs per shift, the VIG will cost approximated two times the cost of an argon gas-filled IG on a per-square-foot basis. This is where ESW predicted the cost would be when it began the Project and is within the upper limits believed acceptable by the Project Collaborators. 


\section{Discussion - Activities, Accomplishments, Key Results}

\subsection{Milestone 30: Determine and Document Test Success/Failure Criteria for TV3's}

\subsubsection{Background:}

The ESW Team, along with the industry collaborators, understood and accepted the challenge to develop testing and performance criteria to be applied to the Test Vehicle 3 (TV3) laboratory prototypes for the purpose of validating the flexible bellows concepts. While some may consider defining test methodology along with acceptance criteria in the Applied Research Stage of a complex device to be premature, ESW has developed a comprehensive plan using input from a variety of individuals with expertise ranging from window industry product development, to reliability, to deep science and physics. The product of this work is a flexible scientific process that ensures solid conclusions out of the proof-ofconcept work and transitions smoothly into the Exploratory Development (TV3) and Advanced Development activities as they occur. In essence the ESW VIG Test and Validation Process has been built as the technical foundation of the eventual completed VIG system.

\section{Key Features of the ESW VIG Test and Validation Process}

ESW is delivering a comprehensive process that exceeds the defined milestone requirements, but is the most appropriate thing to do at this stage of the project. The key features of the process are highlighted below:

\subsubsection{1 "Test Success/Failure Criteria" translates into Customer Wants and Needs:}

Cooper and other authors refer to identification of "customer wants and needs" early in the Applied Research stage as a key best practice. ESW has worked effectively from the outset of the project to develop close interaction and collaboration with potential customers. The very first collaboration activity, occurring in the project Kick-Off Meeting in May of 2006, was to develop a VIG wants and needs list (See Worst Case Environments Tables, below). Although input to and refinement of this work is still underway (also a best practice), the T\&V Process currently contains solid definitions of conditions and stresses that industry experts and potential customers consider keys to success. Thus, the milestone requirements are satisfied from the acceptance criteria side - with well defined criteria that has broad support by potential customers at this early stage of the project.

\subsubsection{2 "Test Success/Failure Criteria" are integrated throughout project phases.}


Performance and reliability goals have been established as part of the process described in 2.1.2.1, above. ESW has integrated key elements of the documented Worst Case Environment performance and stress requirements into the early VIG development stages. Since much of the optimizing for high performance and reliability will occur in TV1 and TV2 formats, the process has been developed to set key technical benchmarks to be met by TV1 and TV2. This which will increase the likelihood that TV3 meets all of the documented requirements while helping to ensure the most rapid progress in developing the key performance and reliability attributes desired by the marketplace.

\subsubsection{ESW VIG's will meet building codes.}

Validation criteria has been established which will ensure that the VIG will meet and exceed all current and anticipated building codes, in-as-much as the "standalone" VIG component influences the performance of the fully configured product.

\subsubsection{Fail Safe Performance:}

While all potential safety issues will be addressed as they are identified, tests are already listed, to provide assurance that if the ESW VIG fails in any mode, it always fails safe.

\subsubsection{Validity of Results:}

It is understood by ESW and all of the industry collaborators that the Worst Case Environments Tables (See Tables below 2.1.2.7) include requirements for the fully configured VIG. This fully configured VIG includes the glass spacer element that is not currently part of this DOE contract. There is consensus understanding that the performance and reliability achieved in the TV3 format will also need to be achieved in the fully configured format, including the required spacers.

\subsubsection{Continuous Improvement:}

As defined in 1.1.1 above, the T\&V Process Plan is a living document which will be updated frequently and will serve as the working tool to monitor the alignment between the "wants and needs" list and the ability of the ESW VIG to meet every item on the list.

\subsubsection{Performance and Reliability Validation:}

While it may be implied in the milestone definition that significant emphasis is placed on the need for reliability validation along with performance, this is not normally the case in the window and door industry today. Solid understandings of the field reliabilities of many of the components of window and door assemblies are elusive at best. ESW recommended and the industry collaborators have supported developing the ESW T\&V to include statistically sound reliability predictive testing all the way from TV1 formats through TV3 
formats. Again, it is understood that further work will need to be done to validate the fully configured VIG, including the glass spacers, but the ESW T\&V Process will be extended to include that phase, retaining and leveraging all of the previous work in the prior design formats. Some of the performance and reliability key features are listed below.

2.1.1.7.1 Since rapid proof of durability against the defined environmental exposures has been identified as a key prerequisite for large-scale industry adoption of the VIG, the ESW T\&V process addresses this.

2.1.1.7.2 ESW has adapted and documented accelerated reliability testing methodologies currently used by the automotive and electronics industries, for use in TV3 iterative design / process improvements, along with reliability predictions for the final configured VIG.

2.1.1.7.3 In addition to meeting the requirement for TV3 success/failure identification, the ESW T\&V includes a combination of accelerated testing and statistically designed experiments in TV1 work to facilitate rapid iterative design and optimization.

2.1.1.7.4 A similar combination of accelerated testing and statistically designed experiments are planned and documented for TV2, using helium leak testing to predict potential vacuum loss. This will speed the development by providing predictions of vacuum leak-free performance prior to the need to build prototypes with internal spacers and vacuum.

2.1.1.7.5 The ESW T\&V is structured to rapidly build strong scientific basis for the anticipated bond component development and improvement (TV1), leading to sub-system (TV2 \& TV3) performance and durability verification. The plan is for this work to seamlessly support the follow-on spacer and fully configured system development efforts as they are initiated. 


\section{Vertical Glazing Worst Case Environments}

Temperature Cycling
\begin{tabular}{|l|l|l|l|l|}
\hline $\begin{array}{l}\text { Worst Case } \\
\text { Conditions }\end{array}$ & $\mathrm{T}_{\mathrm{L}}\left({ }^{\circ} \mathrm{C}\right)$ & $\mathrm{T}_{\mathrm{H}}\left({ }^{\circ} \mathrm{C}\right)$ & Cycles & Rationale \\
\hline $\begin{array}{l}\text { High temp } \\
\text { range }\end{array}$ & 10 & 90 & $1 /$ Day & $\begin{array}{l}\text { Arizona }-75^{\circ} \mathrm{C} \\
\text { measured }+20 \%\end{array}$ \\
\hline $\begin{array}{l}\text { Low temp } \\
\text { range }\end{array}$ & -40 & 10 & $1 /$ Day & $\begin{array}{l}\text { Canada }- \text { Assumed } \\
(\mathrm{TBV})\end{array}$ \\
\hline Max low / high & -40 & 90 & 1 Time & Mfg/ship/install \\
\hline $\begin{array}{l}\text { Shaded stress } \\
\text { range }\end{array}$ & 16 & 60 & $1 /$ Day & Rising sun (TBV) \\
\hline Thermal shock & 10 & 90 & 1000 & $\begin{array}{l}25 \text { rapid transitions } \\
\text { from sun to rain } / \mathrm{yr}\end{array}$ \\
\hline
\end{tabular}

\section{Mechanical Stress}

\begin{tabular}{|l|l|l|l|}
\hline $\begin{array}{l}\text { Worst Case } \\
\text { Conditions }\end{array}$ & Amplitude & Cycles & Rationale \\
\hline $\begin{array}{l}\text { Out of plane } \\
\text { twist }\end{array}$ & $\begin{array}{l}\text { T 5.3.6.4.2- } \\
\text { AAMA/WDMA/CSA } \\
\text { 101/I.S.2/A440 - 05 }\end{array}$ & Per spec & Installation \\
\hline Shear in plane & $1 \mathrm{G}$ & $1 \times 10^{6}$ & Shipment \\
\hline Shear in plane & 100 PSF & $200 \mathrm{X}$ & Handling \\
\hline $\begin{array}{l}\text { COG out of } \\
\text { plane deflection }\end{array}$ & $6 \mathrm{G}$ & $20 \times 10^{6}$ & Wind deflect \\
\hline $\begin{array}{l}\text { Tensile (normal } \\
\text { to joint) }\end{array}$ & $\begin{array}{l}\text { 1G, supported by 1 } \\
\text { glass pane }\end{array}$ & 50 & Mfg \\
\hline Impact - normal & $\begin{array}{l}75 \% \text { ultimate } \\
\text { strength in this } \\
\text { mode }\end{array}$ & 100 & Normal use \\
\hline $\begin{array}{l}\text { External } \\
\text { pressure }\end{array}$ & $27-32$ in. Hg & $6 \times 10^{3}$ & Bar. Press. \\
\hline
\end{tabular}




\section{Chemical Exposure}

\begin{tabular}{|l|l|l|l|}
\hline $\begin{array}{l}\text { Worst Case } \\
\text { Conditions }\end{array}$ & $\begin{array}{l}\text { State I } \\
\text { Concentration }\end{array}$ & Cycles & Rationale \\
\hline Water & Liquid - room temp & 1000 days & Glazing leak \\
\hline Water & Vapor / saturated & Full time $5 \mathrm{yr}$ & Humid climate \\
\hline Mineral spirits & Vapor / saturated & 4 months & Mfg \\
\hline $\begin{array}{l}\text { Isopropyl } \\
\text { alcohol }\end{array}$ & Vapor / saturated & 3 days & Mfg \\
\hline Acetone & Vapor / saturated & 1 day & Mfg \\
\hline Acid - Muriatic & Liquid / 4\% by vol. & 3 months & Masonry construction \\
\hline $\begin{array}{l}\text { Industrial } \\
\text { gasses }\end{array}$ & $\mathrm{SO}_{2} / 12 \mu \mathrm{g} / \mathrm{m}^{3}$ & $12 \mathrm{hr} / \mathrm{yr}$ & Urban locations \\
\hline $\begin{array}{l}\text { Marine } \\
\text { environment }\end{array}$ & $\begin{array}{l}30^{\circ} \text { exposure at } \\
\mathrm{Kure}, \mathrm{NC}, \text { USA }\end{array}$ & 1000 days & Coastal \\
\hline Acid Rain & $5 \mathrm{PH}$ & 100 Days & \\
\hline Fungus & $9 \mathrm{PH}$ & 100 Days & \\
\hline $\begin{array}{l}\text { Sheetrock and } \\
\text { water (vapor) }\end{array}$ & 9 & & \\
\hline
\end{tabular}

\section{Electromagnetic Radiation}

\begin{tabular}{|l|l|l|l|}
\hline $\begin{array}{l}\text { Worst Case } \\
\text { Conditions }\end{array}$ & Intensity & Duration & Rationale \\
\hline Solar Spectrum & $1100 \mathrm{~W} / \mathrm{m} 2$ & $10 \mathrm{~h} /$ day & $\begin{array}{l}\text { Arizona - ASTM } \\
\text { G159-98, ASTM } \\
\text { G173-03e1 }\end{array}$ \\
\hline Ultraviolet & $50 \mathrm{~W} / \mathrm{m} 2$ & $\begin{array}{l}6 \mathrm{~h} / \text { day, } 4000 \\
\mathrm{hr} \text { total }\end{array}$ & Arizona \\
\hline
\end{tabular}




\section{Sloped Glazing Worst Case Environments}

Temperature Cycling
\begin{tabular}{|l|l|l|l|l|}
\hline $\begin{array}{l}\text { Worst Case } \\
\text { Conditions }\end{array}$ & $\mathbf{T}_{\mathrm{L}}\left({ }^{\circ} \mathrm{C}\right)$ & $\mathbf{T}_{\mathrm{H}}\left(^{\circ} \mathrm{C}\right)$ & Cycles & Rationale \\
\hline $\begin{array}{l}\text { High temp } \\
\text { range }\end{array}$ & 60 & 100 & $1 /$ Day & Arizona/tinted \\
\hline $\begin{array}{l}\text { Low temp } \\
\text { range }\end{array}$ & -40 & 10 & $1 /$ Day & Canada \\
\hline Max low / high & -40 & 100 & 1 Time & Mfg/ship/install \\
\hline $\begin{array}{l}\text { Shaded stress } \\
\text { range }\end{array}$ & 15 & 70 & $1 /$ Day & Rising sun \\
\hline Thermal shock & 10 & 90 & 1000 & $\begin{array}{l}25 \text { rapid transitions from } \\
\text { sun to rain / yr }\end{array}$ \\
\hline
\end{tabular}

\section{Mechanical Stress}

\begin{tabular}{|l|l|l|l|}
\hline $\begin{array}{l}\text { Worst Case } \\
\text { Conditions }\end{array}$ & Amplitude & Cycles & Rationale \\
\hline $\begin{array}{l}\text { Out of plane } \\
\text { twist }\end{array}$ & $\begin{array}{l}\text { I 5.3.6.4.2- } \\
\text { AAMA/WDMA/CSA } \\
101 / \text { I.S.2/A440 - 05 }\end{array}$ & Per spec & Installation \\
\hline Shear in plane & $1 G$ & $1 \times 10^{6}$ & Shipment \\
\hline Shear in plane & 100 PSF & $200 \times$ & Handling \\
\hline $\begin{array}{l}\text { COG out of } \\
\text { plane } \\
\text { deflection }\end{array}$ & $6 \mathrm{G}$ & $20 \times 10^{6}$ & Wind deflect \\
\hline $\begin{array}{l}\text { Tensile } \\
\text { (normal to } \\
\text { joint) }\end{array}$ & $\begin{array}{l}\text { 1G, supported by 1 } \\
\text { glass pane }\end{array}$ & 50 & Mfg \\
\hline $\begin{array}{l}\text { Impact - } \\
\text { normal }\end{array}$ & $\begin{array}{l}75 \% \text { ultimate } \\
\text { strength in this mode }\end{array}$ & 100 & Normal use \\
\hline
\end{tabular}




\section{Chemical Exposure}

\begin{tabular}{|l|l|l|l|}
\hline $\begin{array}{l}\text { Worst Case } \\
\text { Conditions }\end{array}$ & $\begin{array}{l}\text { State I } \\
\text { Concentration }\end{array}$ & Cycles & Rationale \\
\hline Water & Liquid - room temp & 1000 days & Glazing leak \\
\hline Water & Vapor / saturated & $\begin{array}{l}\text { Full time 5 } \\
\text { yr }\end{array}$ & Humid climate \\
\hline Mineral spirits & Vapor / saturated & 4 months & $\mathrm{Mfg}$ \\
\hline $\begin{array}{l}\text { Isopropyl } \\
\text { alcohol }\end{array}$ & Vapor / saturated & 3 days & $\mathrm{Mfg}$ \\
\hline Acetone & Vapor / saturated & 1 day & Mfg \\
\hline Acid - Muriatic & $\mathrm{Liquid} / 4 \%$ by vol. $^{3}$ & 3 months & Masonry construction \\
\hline $\begin{array}{l}\text { Industrial } \\
\text { gasses }\end{array}$ & $\mathrm{SO}_{2} / 12 \mu \mathrm{mg} \mathrm{m}^{3}$ & $12 \mathrm{hr} / \mathrm{yr}$ & Urban locations \\
\hline $\begin{array}{l}\text { Marine } \\
\text { environment }\end{array}$ & $\begin{array}{l}30^{\circ} \text { exposure at } \\
\mathrm{Kure}, \mathrm{NC}, \mathrm{USA}\end{array}$ & 1000 days & Coastal \\
\hline Acid Rain & $5 \mathrm{PH}$ & 100 Days & \\
\hline Fungus & See Rationale & $\begin{array}{l}\text { See } \\
\text { Rationale }\end{array}$ & $\begin{array}{l}\text { Fungus Test - Method } \\
\text { 508.5, Procedure I in } \\
\text { MIL-STD 810 F }\end{array}$ \\
\hline
\end{tabular}

\section{Electromagnetic Radiation}

\begin{tabular}{|l|l|l|l|}
\hline $\begin{array}{l}\text { Worst Case } \\
\text { Conditions }\end{array}$ & Intensity & Duration & Rationale \\
\hline $\begin{array}{l}\text { Solar } \\
\text { Spectrum }\end{array}$ & $1100 \mathrm{~W} / \mathrm{m} 2$ & $10 \mathrm{~h} /$ day & $\begin{array}{l}\text { Arizona global - ASTM } \\
\text { G159-98, ASTM G173- } \\
\text { 03e1 }\end{array}$ \\
\hline Ultraviolet & $\begin{array}{l}50 \mathrm{~W} / \mathrm{m} 2 \\
(300-400 \mathrm{~nm})\end{array}$ & $\begin{array}{l}6 \mathrm{~h} / \text { day, } \\
\begin{array}{l}4000 \mathrm{hr} \\
\text { total }\end{array}\end{array}$ & Arizona \\
\hline
\end{tabular}

\section{End Of Worst Case Conditions And Stresses}




\subsection{Milestone 31: Design and Test of the Metal Bellows to Prove Long-Term Reliability}

Note: The entire proprietary Task Report has already been delivered to the DOE EERE and the DOE NETL. The methodology for selecting candidate metals and alloys for the bellows material has also already been delivered to the DOE EERE and the DOE NETL.

\subsubsection{General:}

An evaluation of the mechanics of the vacuum window assembly with a flexible edge bellows resulted in a determination that there would be five principle loads applied to the bellows assembly during fabrication and subsequent service.

2.2.1.1 Stresses and residual stresses associated with an elevated bonding temperature for two materials with different coefficients of thermal expansion (CTE). Since soda lime glass has a lower CTE than most candidate metals for the bellows, cooling from an elevated bonding temperature, either using solder glass or diffusion bonding, would result in the metal component retaining residual tensile stresses.

2.2.1.2 Uniform external pressure will be applied to the bellows assembly due to the high vacuum retained within the VIG unit. We have simply assumed that this pressure is equal to sea level atmospheric pressure of $14.7 \mathrm{psi}$.

2.2.1.3 Differential expansion of the outside glass pane relative to the inside pane due to differential temperatures. These differential environmental temperatures were assumed to be $20 \mathrm{C}$ to $60 \mathrm{C}$ (68F to $140 \mathrm{~F}$ ) for this initial study but could be increased to the maximum range of $20 \mathrm{C}$ to $100 \mathrm{C}$ as the design process continues.

2.2.1.4 Gravity loads associated with the weight of the two glass components supported by the bellows. This load condition was not considered critical at this time and is not investigated in this study.

2.2.1.5 Wind or dynamics loads. Whereas the finished window assembly with spacers will be subjected to dynamic loads, the bellows is expected to be encased in a framing detail and thus would not be subject to significant dynamic loads. This load condition was not considered critical at this time and is not investigated in this study.

2.2.1.6 Residual Stresses: Our initial assumptions on window and metal bellows assemblies were based on common soda lime glass and the characteristics of stainless steel. Since the method of bonding the metal to glass surface has not been defined in detail at this time, we used the assumption of a 
high temperature bonding point and a cool down to ambient conditions. Our goal was to define the boundaries of elevated temperature based on our assumptions of metal and glass characteristics, limited as necessary by the need to be compatible with post tempered low $\mathrm{E}$ glass.

2.2.1.7 Conventional Approach: We conducted a conventional calculation of the expected performance of this bond based on a few assumptions as follows:

2.2.1.8 The ratio of bellows bond area and bellows axial area relative to the glass substrate was assumed to be small. The greater contraction during cooling of the metal component was then assumed to be resisted and dominated by the lesser contraction of the glass and the metal was assumed to not impact the final deformation magnitudes of the glass.

\subsubsection{Calculations}

2.2.2.1 The formulas for axial deformation with uniaxial stresses are as follows:

$$
\begin{array}{ll}
\varepsilon=P L / A E & \\
\text { Where: } & \varepsilon=\text { Strain } \\
& L=\text { the length of the component } \\
& P=\text { Axial force } \\
& A=\text { Area } \\
& E=\text { Modulus of Elasticity }
\end{array}
$$

2.2.2.2 The differential strain of the two bonded materials during cool down is governed by the glass since that area dominates the metal cross section. The differential strain is thus equal to the difference of the metal contraction and the glass contraction. It is shown that the strain in the metal is dependent only on the differential CTE and the temperature range.

$$
\begin{array}{ll}
\varepsilon=\left(e_{s}-e_{g}\right) \Delta T L & \\
\text { Where: } \quad e_{s}=\text { Steel CTE } \\
\mathrm{e}_{\mathrm{g}}=\text { Glass CTE }
\end{array}
$$

2.2.2.3 Characterizing the resulting axial force in the bellows bond flange based on the restrained metal contraction is done by solving for $P$ in the formula above in \#2:

$$
P=\varepsilon A E / L
$$

Substituting for $\varepsilon$ in the above expression:

$$
P=\left(e_{s}-e_{g}\right) \Delta T A E
$$


The uniaxial tensile stress (P/A) in the bellows flange is thus dependent only on the differential CTE, the temperature range from bonding point to ambient, and the elastic modulus of the metal material.

2.2.2.4 We used a test FEA model to confirm these results, first with based on a symmetric model that represents a $4 \times 4$ foot square window. Calculating the tensile strain in the flange for a delta-T of $1300 \mathrm{~F}$ results in a tension of 188.5 lbs. The stress level in the metal is thus $188.5 / 0.005=37,700$ psi. Our parameters of differential CTE and temperature range were selected to create yield in a typical stainless steel.

2.2.2.5 The stress level would be less if the bonding temperature were correspondingly less. For solder glass bonding temperatures roughly half that of diffusion bonding, the stress in the metal component would be half.

2.2.2.6 For purposes of evaluating bonding strengths, metal to glass, the shear stress at the bond interface can also be estimated based on this conventional approach. The shear stress is approximately $3 \mathrm{ksi}$ at the bond interface.

\subsubsection{Finite Element Analysis Approach:}

We also modeled this simple geometry in order to confirm that the shear stress is constant along the bond line for any length, and with all other variables constant, is only dependent on the differential CTE. We used the same parameters as in the above calculation and a differential CTE of $1 \mathrm{e}^{\wedge}-6 / \mathrm{F}$. This would be represented by a stainless steel with $\mathrm{CTE}=5.0 \mathrm{e}^{\wedge}-6 / \mathrm{F}$ and glass with $\mathrm{CTE}=$ $4.0 \mathrm{e}^{\wedge}-6 / \mathrm{F}$

\subsubsection{Conclusions}

2.2.4.1 Edge effects dissipate rapidly, with shear stress rising from zero at the free edge to the maximum value within a distance of approximately 4 to 6 inches. This suggests that the impact of differential CTE would not be apparent in specimens with dimensions on the order of 4 inches or less.

2.2.4.2 The maximum tensile and shear stress are constant along the bond line and independent of bond length. Agreement between the conventional calculation and the FEA model is good.

2.2.4.3 There may be some impact of bellows tensile stresses on the glass free shape though this will likely be mitigated by the two opposing glass panes and the external pressure. An effort should be made, however, to minimize the metal area in tension and thus the tensile forces along the edges of the glass. 
2.2.4.4 The symmetrical pairs of top-side and bottom-side bellows (Lite 1 bellows and Lite 2 bellows) should meet all performance requirements for VIGs with glass surface areas up to 4 feet square. For larger VIGs, a non-symmetrical bellows design (bellow pair) will probably be required if minimizing the length and/or width of the protrusion of the bellows from the edge of the glass panes is deemed necessary.

\subsection{Milestone 32: Production Cost Prediction}

\subsubsection{Background:}

Costs for a fully configured VIG have been estimated, based on the current ESW technical vision. Clearly this is a very early cost prediction and it is based on several key assumptions (see below), which will be systematically validated over the course of this and follow-on projects. The value for cost comparison is cost per square foot at the IG level and cost for fully configured average window - common methods to compare costs in the window industry today.

\subsubsection{Summarized Conclusions From Preliminary Production Cost Prediction Study.}

Summarized comparative costs are listed in the table below:

\begin{tabular}{|c|c|c|}
\hline Item & Cost or Comparison & Value \\
\hline \multicolumn{3}{|c|}{ Component Costs } \\
\hline \multicolumn{3}{|c|}{ ESW VIG: Estimated cost per Ft ${ }^{2}$} \\
\hline 2 & Current low-E, argon-filled IG: Cost per Ft ${ }^{2}$ & $\$ 7.90$ \\
\hline \multicolumn{3}{|c|}{ Comparison At Component Level } \\
\hline 3 & $\begin{array}{c}\text { ESW VIG with Low-E; } \\
\text { Compared to current 2-pane, low-E, argon-filled }\end{array}$ & $+111 \%$ \\
\hline 4 & $\begin{array}{c}\text { ESW VIG with Low-E; } \\
\text { Compared to current 3-pane, low-E, argon-filled }\end{array}$ & $-16 \%$ \\
\hline 5 & $\begin{array}{c}\text { ESW VIG with Low-E; } \\
\text { Compared to current 3-pane, low-E, krypton-filled }\end{array}$ & $-27 \%$ \\
\hline \multicolumn{3}{|c|}{ Comparison at Whole Product Level (Window Product) } \\
\hline 6 & $\begin{array}{c}\text { Window product with ESW VIG with low-E; } \\
\text { Compared to window product with current 2-pane, low-E, } \\
\text { argon-filled IG }\end{array}$ & $+16 \%$ \\
\hline 7 & $\begin{array}{r}\text { Window product with ESW VIG with low-E; } \\
\text { Compared to window product with current 3-pane, low E, }\end{array}$ & $-31 \%$ \\
\hline
\end{tabular}


krypton-filled IG

\subsubsection{General Approach}

2.3.3.1 Since costs for fully-assembled windows (includes doors, skylights) vary by materials, one "average" residential window configuration has been assumed for this preliminary study: medium priced vinyl.

2.3.3.2 Since costs for fully-assembled windows (includes doors, skylights) vary by size, a 7 square foot standard size, representative of current residential windows, was chosen for this preliminary study. This is customary to allow relative cost comparisons.

2.3.3.3 Based on the "average" window defined above, the current gasfilled IG is assumed to represent $10 \%$ of the total cost to the consumer.

2.3.3.4 While this preliminary study does not specifically include skylights and commercial products, it is assumed that the general cost relationships are similar.

2.3.3.5 Since the final production process is not defined yet, this preliminary analysis conservatively assumes production machinery costs that are tripled over today's investments.

2.3.3.6 Material costs were estimated based on high volume glass, fiberglass and 17-4 PH stainless steel representative prices.

Note: The entire Production Cost Prediction Task Report, including assumptions and rationale for conclusions, has already been delivered to the DOE EERE and DOE NETL. 


\section{Cost Status}

\subsection{Budget Period 1 Cost Status}

\begin{tabular}{|l|r|r|rr|}
\hline \multicolumn{1}{|c|}{ Description } & $\begin{array}{c}\text { Approved } \\
\text { Budget for BP1 }\end{array}$ & $\begin{array}{c}\text { Final Submittal } \\
\text { to VIPERS } \\
\text { (DOE ORNL) on } \\
\text { Nov. 17, 2006 }\end{array}$ & $\begin{array}{c}\text { Remaining } \\
\text { (Unspent) at the } \\
\text { Completion of } \\
\text { BP1 }\end{array}$ \\
\hline DOE Share & $\$ 308,400.00$ & $\$ 308,259.08$ & $\$$ & 140.92 \\
\hline Recipient Share & $\mathbf{7 7 , 1 0 0 . 0 0}$ & $77,064.77$ & & 35.23 \\
\hline & & & & 176.15 \\
\hline Totals & $\$ 385,500.00$ & $\$ 385,323.85$ & $\$$ & \\
\hline
\end{tabular}

\section{Schedule Status}

\subsection{Status of BP1 Tasks}

Table 4.1.1 shows the status of the DOE's three milestones for BP1 to decide whether the Project should proceed to BP2. Table 4.1.2 shows the status of the EverSealed tasks leading to the assembling and testing the TV1 specimens.

\subsubsection{The DOE's Three Major Milestones for BP1}

\begin{tabular}{|c|l|c|c|}
\hline $\begin{array}{c}\text { The } 3 \text { Major } \\
\text { Milestones }\end{array}$ & \multicolumn{1}{|c|}{ Description } & $\begin{array}{c}\text { Planned } \\
\text { Complete }\end{array}$ & $\begin{array}{c}\text { Actual } \\
\text { Complete }\end{array}$ \\
\hline 30 & $\begin{array}{l}\text { Determine and document test } \\
\text { success/failure criteria for TV3's }\end{array}$ & $\begin{array}{c}\text { August } \\
2006\end{array}$ & $\begin{array}{c}\text { October } \\
2006\end{array}$ \\
\hline 31 & $\begin{array}{l}\text { Design and test of the metal bellows } \\
\text { to prove long-term reliability }\end{array}$ & $\begin{array}{c}\text { August } \\
2006\end{array}$ & $\begin{array}{c}\text { October } \\
2006\end{array}$ \\
\hline 32 & Production Cost Prediction & $\begin{array}{c}\text { October } \\
2006\end{array}$ & $\begin{array}{c}\text { October } \\
2006\end{array}$ \\
\hline
\end{tabular}

\subsubsection{ESW's BP1 Tasks Towards the Completion of TV1}

\begin{tabular}{|c|l|c|c|}
\hline TV1 Tasks & \multicolumn{1}{|c|}{ Description } & $\begin{array}{c}\text { Planned } \\
\text { Complete } \\
(\mathbf{2 0 0 6})\end{array}$ & $\begin{array}{c}\text { Actual } \\
\text { Complete } \\
(\mathbf{2 0 0 6})\end{array}$ \\
\hline 4 & Plan / Design The Test Vehicles \#1 & August & September \\
\hline
\end{tabular}




\begin{tabular}{|c|c|c|c|}
\hline & (TV1) & & \\
\hline 5 & $\begin{array}{l}\text { Materials Selection For Initial Bonding } \\
\text { Trials (TV1): Glass }\end{array}$ & August & May \\
\hline 6 & $\begin{array}{l}\text { Materials Selection For Initial Bonding } \\
\text { Trials (TV1): Frame/Bellows Materials: } \\
\text { Determine best metals or alloys for } \\
\text { the U.S. supplier's window glasses }\end{array}$ & August & August \\
\hline 7 & Acquire materials for TV1 & September & October \\
\hline 8 & $\begin{array}{l}\text { Intermediate Process Development: } \\
\text { Oxidation of metals/alloys }\end{array}$ & November & October \\
\hline 9 & $\begin{array}{l}\text { Characterize And Document The } \\
\text { Thermal Properties Of Glass Test } \\
\text { Specimens At Elevated Temperatures } \\
\text { (using system such as a Perkin Elmer } \\
\text { Dynamic Mechanical Analyzer (DMA) } \\
\text { instrument), or in a VPE chamber }\end{array}$ & October & $\begin{array}{l}\text { Revised to } \\
\text { January } \\
2007\end{array}$ \\
\hline
\end{tabular}

\subsection{The Negotiated Work Breakdown Structure (WBS) or Work Plan for the Three Budget Periods}

The Work Plan is a living or dynamic plan that accommodates thoughtful changes to this R\&D effort as new discoveries are made. Some discoveries will be beneficial, leading to better-than expected results. Other outcomes might be detrimental and require different paths and methods to be pursued.

The final WBS negotiated for the contract award is shown in the following two tables. Table 4.2.1 shows the Work Plan for the TV1 effort, Table 4.2.2 shows the TV2 Work Plan and the TV3 Work Plan is shown in Table 4.2.3. 
Table 4.2.1. The TV1 Project Phase

\begin{tabular}{|c|c|c|c|c|c|c|c|c|c|c|c|c|c|c|c|c|}
\hline & TASK / MILESTONE & & & & & & & & & & & & & & & \\
\hline No. & DESCRIPTION & Depend & & $\begin{array}{l}\text { End } \\
\text { ath) }\end{array}$ & & & & & & re & & & & & & \\
\hline & & & Start & End & & Q1 & & & Q2 & & & Q3 & & & Q4 & \\
\hline & & & & & 1 & \begin{tabular}{|l|}
2 \\
\end{tabular} & 3 & 4 & 5 & 6 & 7 & 8 & 9 & 10 & & 12 \\
\hline & & & & & & & & & & & & & & & & \\
\hline & & & & & & & & & & & & & & & & \\
\hline 1 & $\begin{array}{l}\text { Contract Negotiations With the } \\
\text { DOE/NETL }\end{array}$ & N/A & & & & & & & & & & & & & & \\
\hline 2 & Project Kick-off & 1 & 0.0 & 0.6 & & & & & & & & & & & & \\
\hline 3 & $\begin{array}{l}\text { Briefing/Technical Presentation To } \\
\text { The COR At The COR's Facility } \\
\text { (Within } 30 \text { Days Of Contract Award) }\end{array}$ & 2 & 0.6 & 0.9 & & & & & & & & & & & & \\
\hline Test & Vehicles \#1 (TV1) & & & & & & & & & & & & & & & \\
\hline Obje & ective: Develop best match of metal & & & & & & & & & & & & & & & \\
\hline 4 & $\begin{array}{l}\text { Plan I Design The Test Vehicles \#1 } \\
\text { (TV1) }\end{array}$ & 2,3 & 0.9 & 1.6 & & & & & & & & & & & & \\
\hline 5 & $\begin{array}{l}\text { Materials Selection For Initial Bonding } \\
\text { Trials (TV1): Glass }\end{array}$ & 2 & 0.5 & 1.3 & & & & & & & & & & & & \\
\hline 6 & $\begin{array}{l}\text { Materials Selection For Initial Bonding } \\
\text { Trials (TV1): Frame/Bellows Materials: } \\
\text { Determine best metals or alloys for } \\
\text { the U.S. supplier's window glasses }\end{array}$ & 2,5 & 1.3 & 2.4 & & & & & & & & & & & & \\
\hline 7 & Acquire materials for TV1 & 5,6 & 2.4 & 3.5 & & & & & & & & & & & & \\
\hline 8 & $\begin{array}{l}\text { Intermediate Process Development: } \\
\text { Oxidation of metals/alloys }\end{array}$ & 7 & 3.5 & 4.5 & & & & & & & & & & & & \\
\hline 9 & $\begin{array}{l}\text { Characterize And Document The } \\
\text { Thermal Properties Of Glass Test } \\
\text { Specimens At Elevated Temperatures } \\
\text { (using system such as a Perkin Elmer } \\
\text { Dynamic Mechanical Analyzer (DMA) } \\
\text { instrument), or in a VPE chamber }\end{array}$ & 7 & 3.1 & 3.5 & & & & & & & & & & & & \\
\hline 10 & Perform Initial Bonding Trials (TV1) & $\begin{array}{c}7,8,9 \\
33\end{array}$ & 5.1 & 7.3 & & & & & & & & & & & & \\
\hline 11 & $\begin{array}{l}\text { DOE I PROJECT TEAM DECISION } \\
\text { POINT ON WHETHER TO CONTINUE } \\
\text { PROJECT }\end{array}$ & 10 & 7.3 & 7.6 & & & & & & & & T & & & & \\
\hline 12 & $\begin{array}{l}\text { Annual Report at the End of TV } 1 \\
\text { Phase }\end{array}$ & 10,11 & 7.6 & 7.9 & & & & & & & & & & & & \\
\hline & NEW DOE TASKS & & & & & & & & & & & & & & & \\
\hline 30 & \begin{tabular}{|l|} 
Determine and document test \\
success/failure criteria for TV3's
\end{tabular} & 1,2 & 0.0 & 1.3 & & & & & & & & & & & & \\
\hline 31 & $\begin{array}{l}\text { Design and test of the metal bellows } \\
\text { to prove long-term reliability }\end{array}$ & 6.1 & 0.0 & 2.0 & & & & & & & & & & & & \\
\hline 32 & Production Cost Prediction & $2,5,31$ & 0.3 & 4.7 & & & & & & & & & & & & \\
\hline 33 & $\begin{array}{l}\text { DoE I PROJECT TEAM DECISION } \\
\text { POINT ON WHETHER TO CONTINUE } \\
\text { PROJECT - Based on outcome of } \\
\text { Tasks } 30-32\end{array}$ & $30,31,32$ & 4.7 & 5.1 & & & & & & & & & & & & \\
\hline
\end{tabular}


Table 4.2.2. The TV2 Project Phase

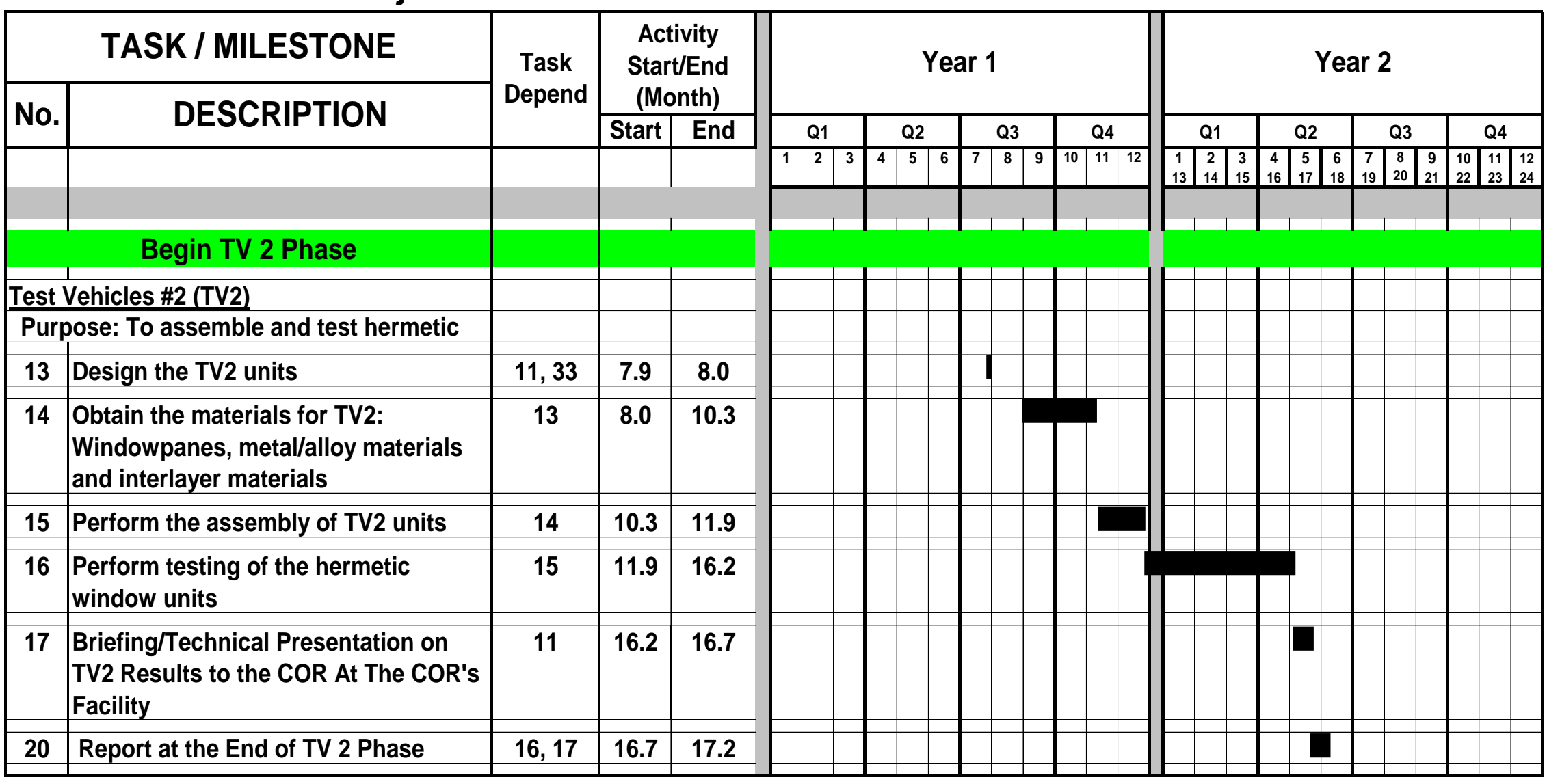


Table 4.2.3. The TV3 Project Phase

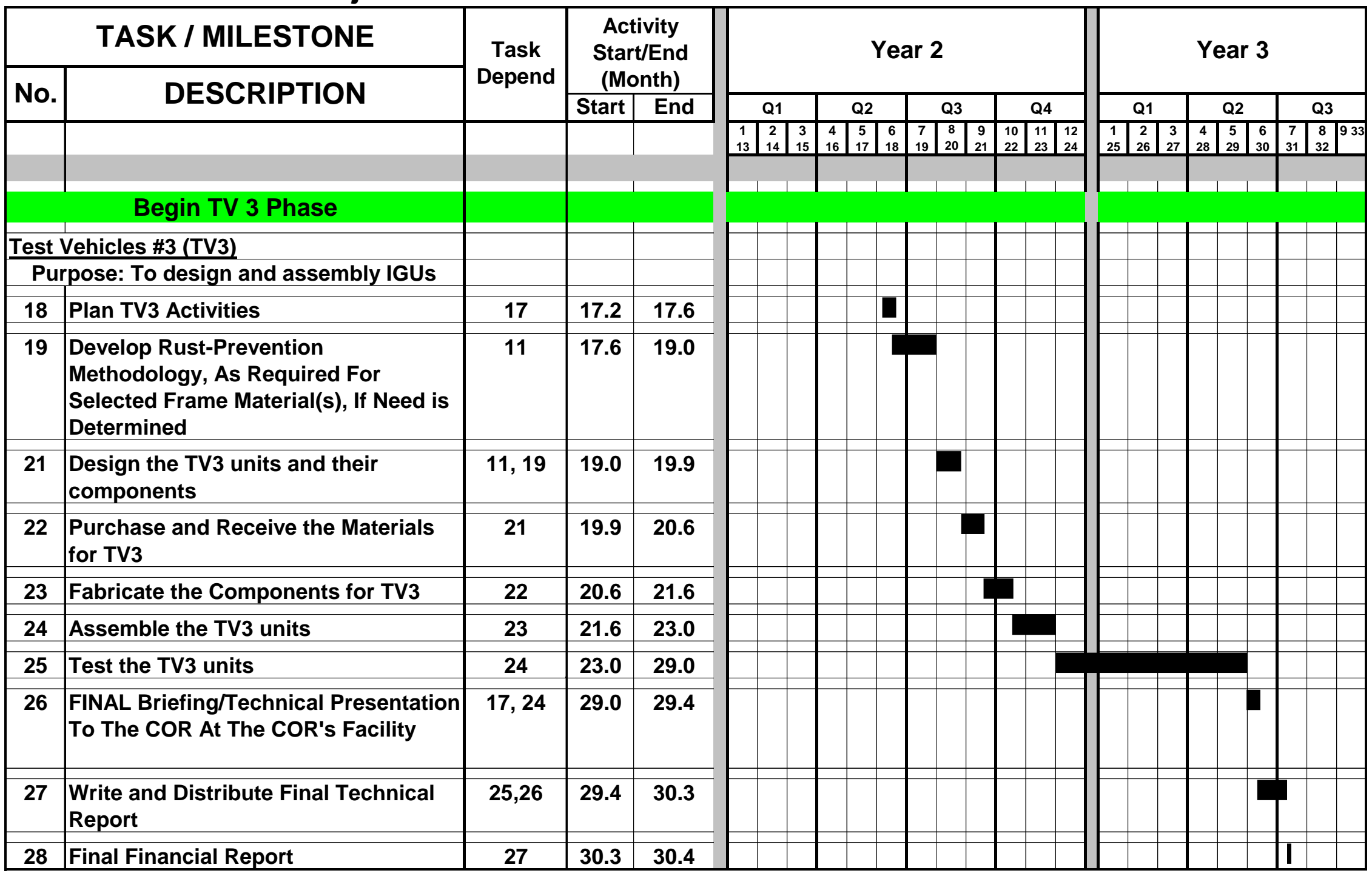




\section{Changes in Approach - Rationale}

\subsection{Solder Glass Bond}

At the Project's first Briefing/Technical Presentation to the COR, on June 28, 2006 at the EERE D.C. Headquarters, ESW discussed potential bonding temperatures that might be used to join the metal bellows to the soda-lime float glass, and the possible advantages of using solder glass as a bonding interface material in lieu of diffusion bonding. Solder glass, if it can provide a bond that meets the end-item requirements for strength, durability and hermeticity, might be a lower cost alternative to the diffusion bonding process for joining the bellows to the float glass.

As a result of these discussions, ESW agreed at this meeting to investigate using solder glass in parallel with its development of diffusion bonding the bellows to the soda-lime float glass.

\subsection{Industry Collaboration on Success/Failure Criteria: Project's Task 30}

When the DOE asked ESW to perform this milestone, the goal was for ESW to develop and document a Test and Validation Plan (T\&V Plan) that the glass and window industry users would find to be valid and acceptable. But rather than develop a plan and then try to obtain broad industry consensus, ESW instead has involved some of the largest U.S. glass producers and window and door manufacturers at the onset of developing the requirements for TV3 and the subsequent test methods to validate TV3 meeting those requirements. 


\section{Actual or Anticipated Problems or Delays}

ESW does not anticipate and problems or delays.

\section{Absences or Changes in Collaborators}

\subsection{Larry Edson (General Motors).}

Larry was brought on board to support the design and execution of accelerated test methods for all three test vehicles (TV1, TV2 and TV3).

\subsection{Edward Boulos, PhD.}

Ed joined the team to provide glass science expertise.

\section{Product Produced or Technology Transfer Activities Accomplished During this Reporting Period.}

As mentioned above in Section 2.1: "Milestone 30: Determine and document test success/failure criteria for TV3's", ESW took the unusual but efficient path of creating the T\&V Process Plan with the industry as a collaborator in the effort. Inputs to this plan came from the following ESW collaborators:

- Two (2) Float Glass producers.

- $\quad$ Two of the largest soda-lime float-glass producers in the U.S.

- Two (2) Residential window and door manufacturers.

- $\quad$ Two of the largest residential window and door producers in the U.S.

- One (1) Commercial window and door manufacturer.

- The U.S. manufacturing subsidiary of the world's largest skylight producer. 


\section{This page is intentionally left blank.}




\section{Budget Period \# 2}

\section{Summary of BP2 Project Goals Accomplished or Missed}

Based on the accomplishments in BP-1, the DOE held a go/no-go meeting in Washington, DC in mid-November 2006 and moved the Project into Budget Period 2 (BP-2). During this go/no-go meeting, the DOE expressed a concern that ESW did not have a back-up plan or process should ESW be unable to make its diffusion bonding process more than adequate for the necessary bond strength and hermeticity of the seal. ESW suggested and volunteered to investigate using a glass frit (i.e., solder glass) as a back-up to its diffusion bonding of glass to oxidized metal.

\subsection{The Two Milestones for BP2}

BP-2 had two deliverables or milestones.

\section{Milestones:}

A) Develop and demonstrate the best match of glass and metal by assembling and testing the bond strength of Test Vehicle 1 (TV-1) components. This deliverable is Tasks 4 through 10. ESW will destructively load-test 10 TV-1 parts in shear with no thermal cycling of these parts, and 10 additional TV-1 parts after exposing them to 250 thermal cycles from -30 degrees $C$ to +60 degrees $C$. See Table 4.2.1 on Page 21.

Task 9 was originally part of BP-1, but was completed in BP-2. This was for ESW is to characterize and document the thermal properties (Coefficient of Thermal Expansion, CTE) of glass test specimens at elevated temperatures.

B) Assemble and test sealed packages to determine the level of hermeticity of ESW's glass-to-metal bond methodology. ESW is to create a quantity of Test Vehicle 2 (TV-2) parts and to perform hermeticity tests on them prior to and after exposing them to 250 thermal cycles from -30 degrees $C$ to +60 degrees $C$. This deliverable is Tasks 12 though 16 . See Table 4.2.2 on Page 22. 


\section{Discussion - Activities, Accomplishments, Key Results of BP2}

\subsection{TV-1, Tasks 4 through 10: Develop the Best Material Match of Metal to Soda-Lime Float Glass; Develop and Demonstrate and Test the Mechanical Strength of Glass- to-Metal Bonds}

\subsubsection{Glass-to-Metal Bonding Development}

\subsubsection{Diffusion Bonding and Fusing Glass to Metal}

During 2007 and 2008, ESW attempted to bond a few types of stainless steels which ESW oxidized to soda lime float glass. Bond methods included diffusion bonding fusing the alloys to the glass. The CTE of the metal alloys were a minimum of $1 \mathrm{ppm} /$ degree $\mathrm{C}$ different from the glass. In most instances, the CTE of the stainless steel from the bonding temperature back to ambient was at least $1 \mathrm{ppm} /$ degree $\mathrm{C}$ greater than the corresponding CTE of the glass. This CTE delta resulted in the bond region below the metal and in the bulk glass being under great compression and the region surrounding the bond being in high tension. As a result, the glass around the glass-to-metal bond fractured anywhere from almost instantaneously after the coupon reached ambient temperature to a few days after bond creation. ESW attempted to solve this problem by creating an elevated platform of glass on the glass coupon, so that the stresses would be only compressive stresses, but could not resolve the problem this way.

In mid-2009, ESW started experimenting with an alloy not of the stainless steel variety. After oxidizing this specialty metal alloy, ESW was able to bond this alloy to glass by both high-temperature fusing and much lower temperature diffusion bonding, and in both instances the bonds did not exhibit the high compressive and tensile stresses that resulted with prior trials which used stainless steels. However, ESW could not find a suitable oxidation process that would ensure a permanent glass-to-metal bond as it had achieved with the stainless steels ESW oxidized with its proprietary stainless steel oxidation method.

\subsubsection{Solder-Glass Bonding Glass to Metal}

ESW also worked extensively with Heraeus to determine if they could supply ESW with a solder glass that could bond one or more candidate alloys to sodalime float glass. After extensive experimentation, ESW and Heraeus decided that Heraeus would not be able to supply a solder glass appropriate for ESW's 
intended use.

(http://semiconductor.heraeus.com/en/startseitehome/Halbleiterindustrie.aspx)

In late 2009, ESW embarked on developing a material and process to bond a recently identified metal alloy to soda-lime glass using an in-house developed solder glass as the glass-to-metal interface. In early 2010, ESW was bonding glass to metal with repeatable, reliable results.

\subsubsection{Testing the TV-1 Parts}

In the spring of 2010, ESW produced 20 TV-1 parts to test the strength of the glass-to-metal bonds. Half of the parts were shear-strength tested without any pre-conditioning or induced stressing of the coupons. The other half of the 20 parts were thermal cycled 250 times from -30 degrees $C$ to +60 degrees $C$. The thermal ramp rate of the parts themselves was 3 degrees per second and the parts were held at the thermal extremes of -30 and +60 degrees $C$ for 10 minutes. Thus, the total cycle time from -30 to +60 and back to -30 with the two dwells was 80 minutes per complete cycle.

The shear strength tests were performed by one of ESW's Project Collaborators. The non-conditioned or thermal cycled parts had an ultimate bond shear strength of about 2X the maximum shear stress that would occur in the corner of a 2' by 3' VIGU when lite 1 was at +100 degrees $C$ and lite 2 was at an ambient of +20 degrees $C$ (an 80 degree $C$ delta). Thermal cycling increased the bonds' strength an average of about $30 \%$, providing an even greater safety factor.

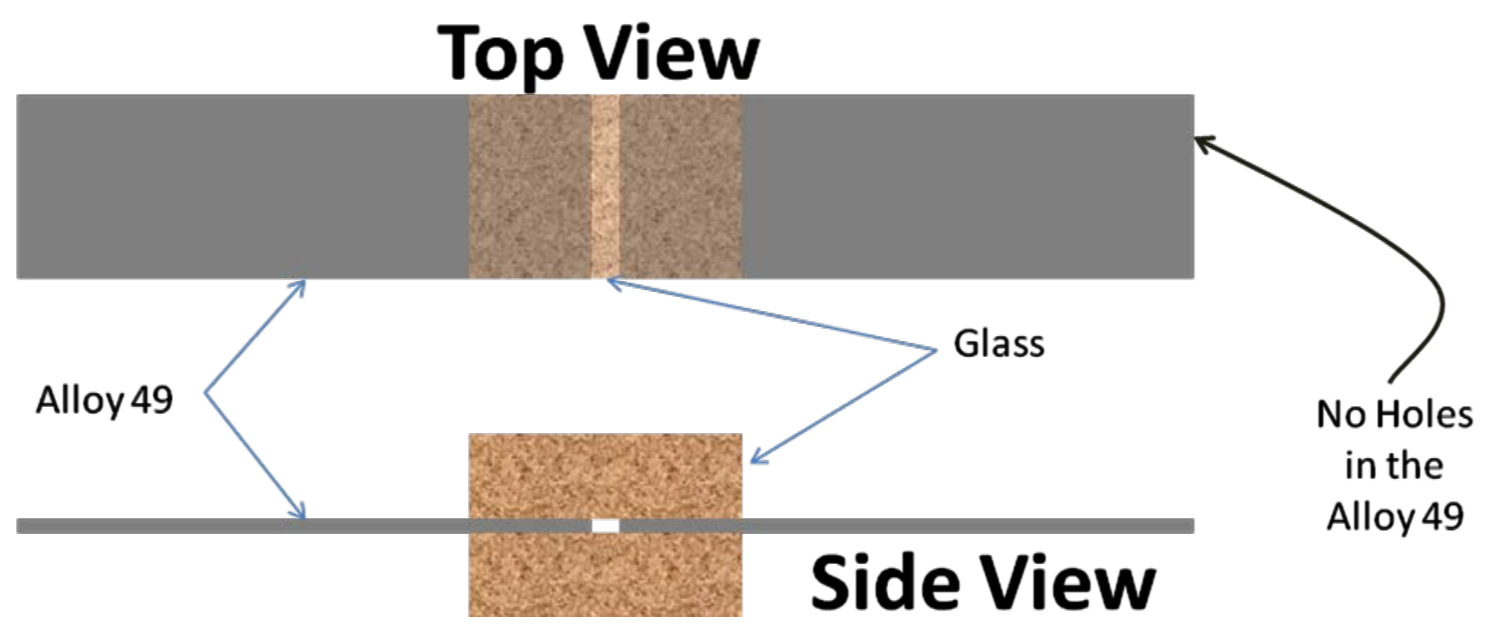

Figure 1. A rendering of the TV-1 coupon 


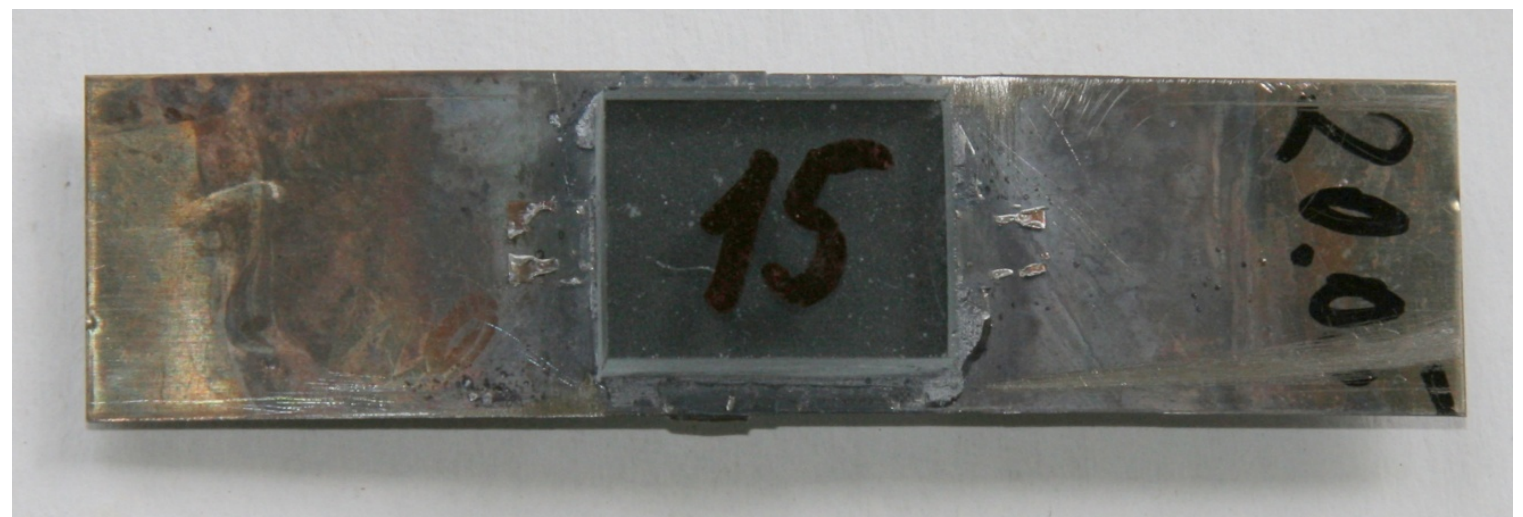

Figure 2. Top view of one of the twenty TV-1 coupons (Coupon \# 15 of 20).

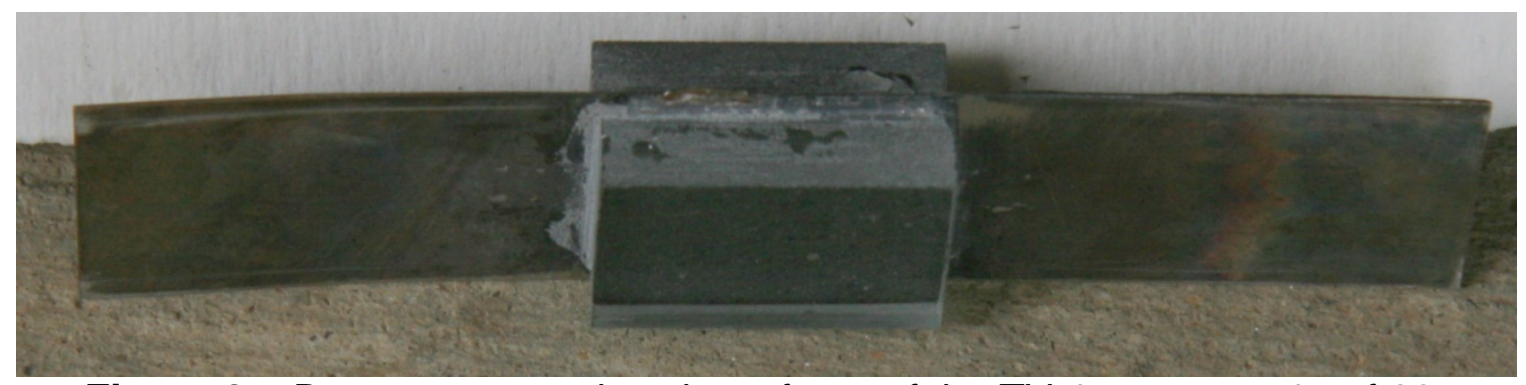

Figure 3. Bottom perspective view of one of the TV-1 coupon \# 15 of 20.

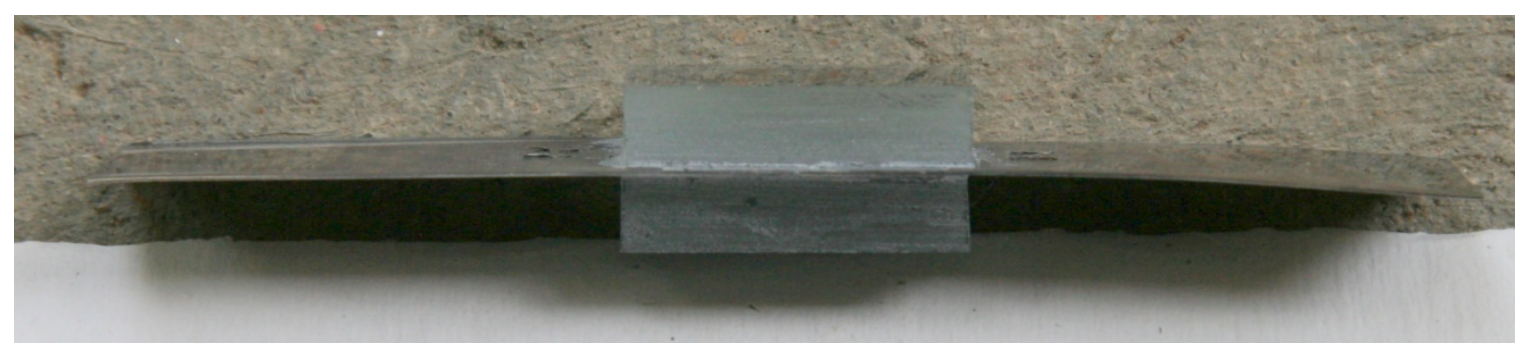

Figure 3. Side view of TV-1 coupon \# 15 of 20. 
EverSealed Windows, Inc.
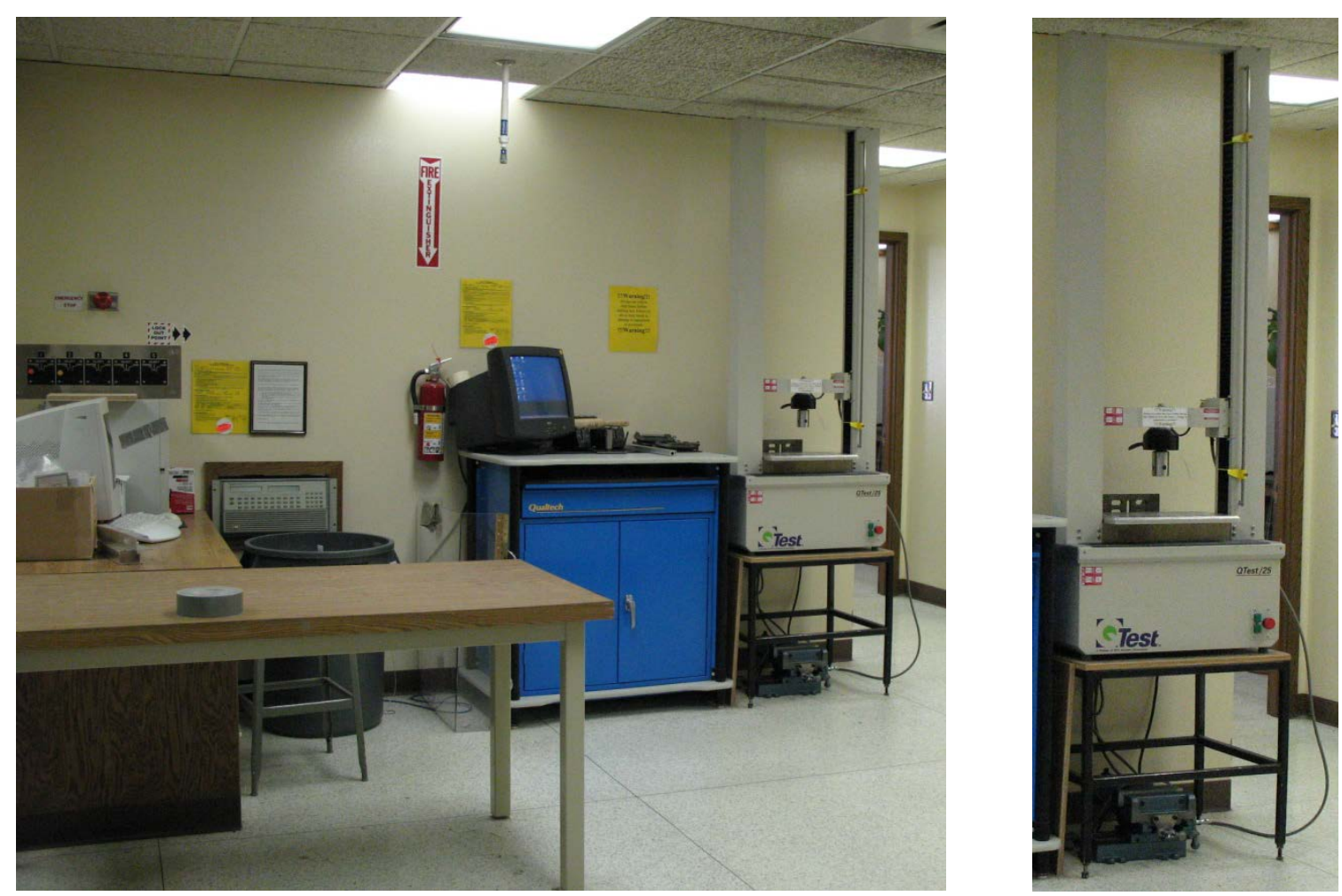

Figure 4. The MTS Q-Test/25 load cell used to measure shear strength of the ESW glass-to-metal bonds. 


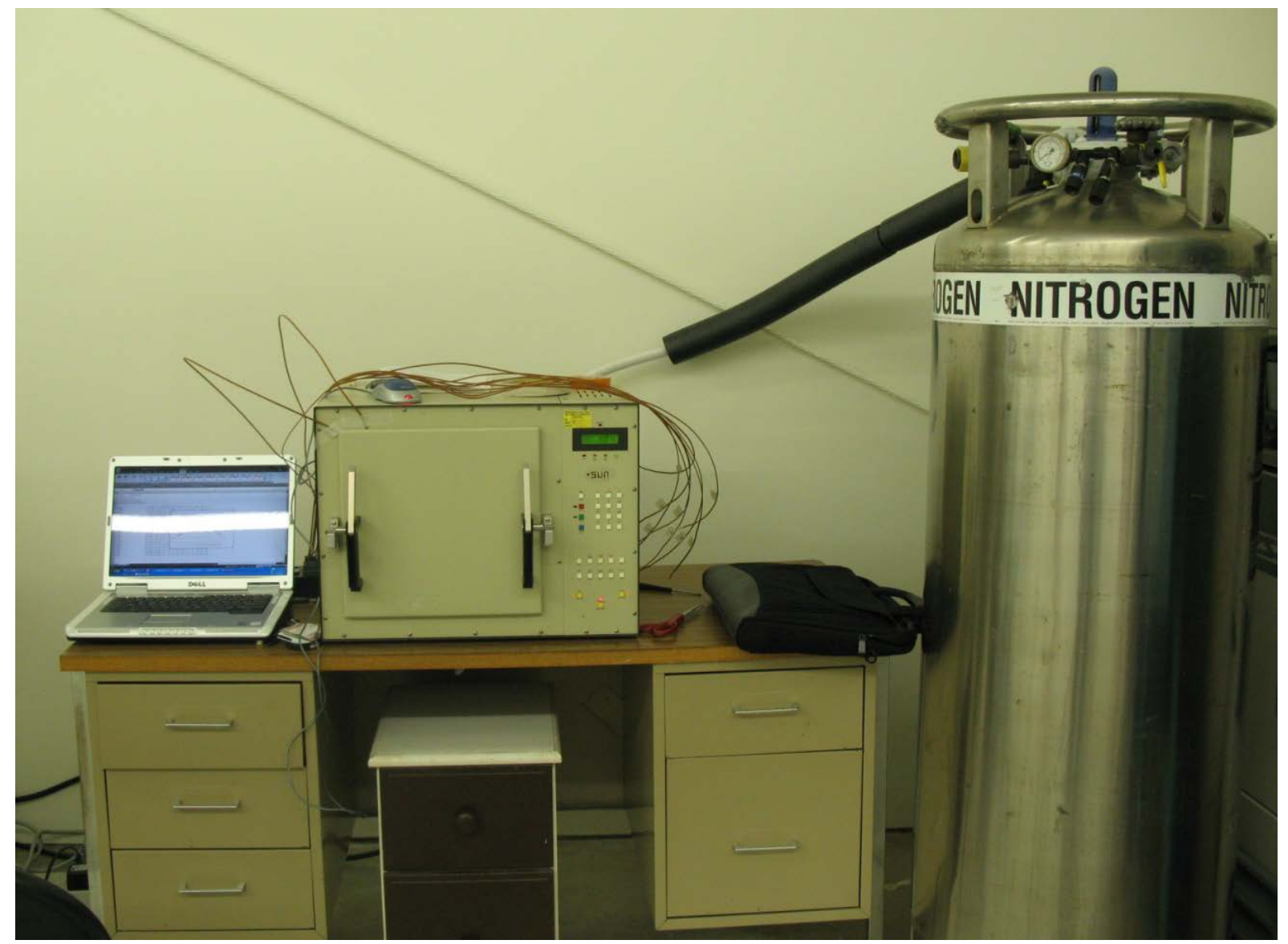

Figure 5. The Sun Electronics Model Number EC10 Environmental Chamber used to thermal cycle half of the TV-1 parts prior to shear strength testing the glass-to-metal bonds.

\subsection{TV-2, Tasks 13 through 16: Design, assemble and test parts to determine the hermeticity of EverSealed Windows' glass-to-metal bonds}

\subsubsection{The Purpose for the TV-2 Parts}

The service life of vacuum sealed windows can be limited by leaks in the edge seal that initiate due to stresses in thermal cycling. ${ }^{i}$ EverSealed undertook a series of helium $(\mathrm{He})$ leak testing and permeation experiments to understand the reliability of its sealing technology. Test Vehicle \# 2 (TV-2) parts were designed and assembled to test and determine the level of hermeticity of the glass-tometal bonds. 


\subsubsection{The Test Methodology for the TV-2 Parts}

Helium $(\mathrm{He})$ leak-rate testing for 8 samples was performed before thermal cycling from $-30^{\circ} \mathrm{C}$ to $+60^{\circ} \mathrm{C}$, and at 50 -cycle intervals for a total of 250 thermal cycles.

Each test followed a standard protocol for fine leak testing using the He bombing method. Images of the samples, sample chamber and test equipment are shown in Figures 1 through 5, below.

At each test point before and after each of the 50 thermal cycles for the total of 250 thermal cycles:

1. The parts were pressurized ("bombed") with $60 \mathrm{psi}$ (4 atmospheres pressure) of He for 24 hours. If the part was leaky, helium will have penetrated the seal during this time.

2. The parts were individually placed in a vacuum chamber and cryopumped to lower the pressure (Figure 5). The cryopumping process does not remove helium from the chamber (since helium is non-condensable). Helium is detected by the mass spectrometer; any helium present above a specific cut-off threshold is indicative of a "gross leak".

3. In the next step of the process, the parts were quickly pumped down to very low pressure. If there were a fine leak in the glass-to-metal seals of the part, helium would continue to flow from the sample after the baseline pressure was reached, and this helium would be detected by the mass spectrometer. A "fine leak" rate for the device was established by monitoring this helium signal over time.

4. The data was plotted over time (Figure 7).

' Matthias M. Koebel, Heinrich Manz, Karl Emanuel Mayerhofer, Beat Keller, "Service-life limitations in vacuum glazing : A transient pressure balance model", Solar Energy Materials \& Solar Cells, 94(2010),1015-1024 


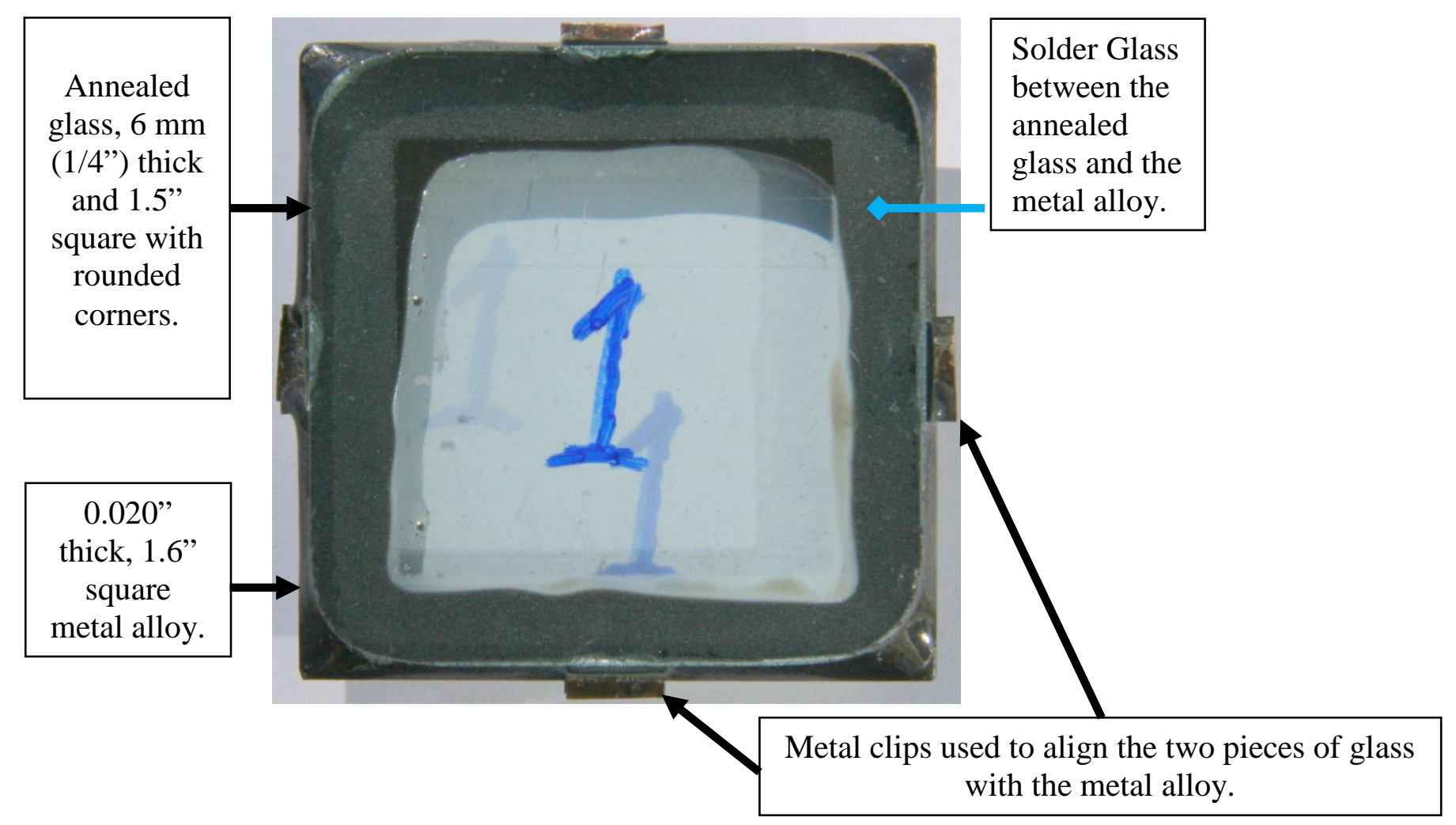

Figure 6. A TV-2 part seen from above.

The window samples measure $3.8 \mathrm{~cm}$ on a side. To prepare them, sealing glass is dispensed by hand around the perimeter of $6 \mathrm{~mm}$ window glass, and then is bonded to metal using EverSealed's process. The window size is dictated by the capacity of the sample chamber, see Figure 4 below.

This and other photos of the top side of the TV-2 parts were taken outdoors in sunlight. The numbers on the outside of one of the pieces of glass cast a shadow on the paper the parts were placed upon. 


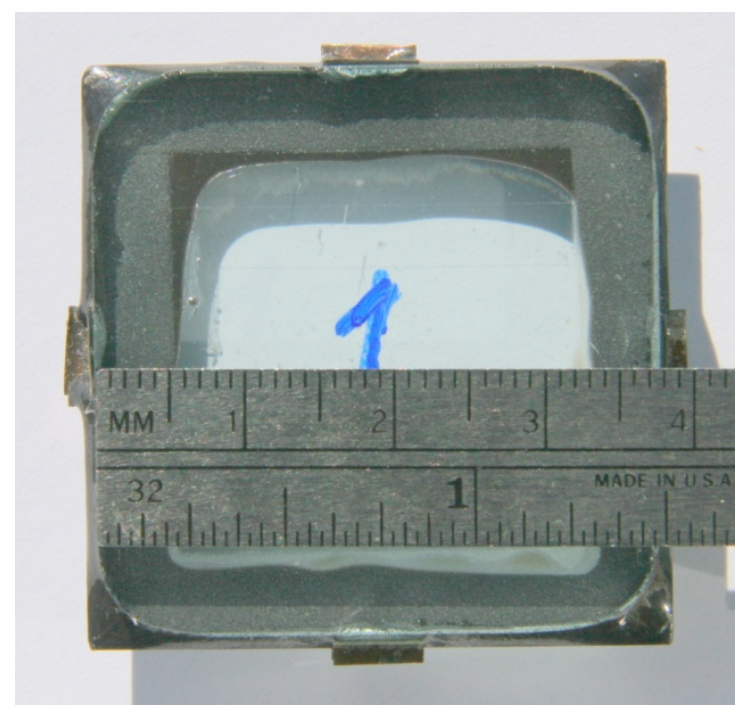

Figure 7. A TV-2 part with a scale placed on the glass surface.

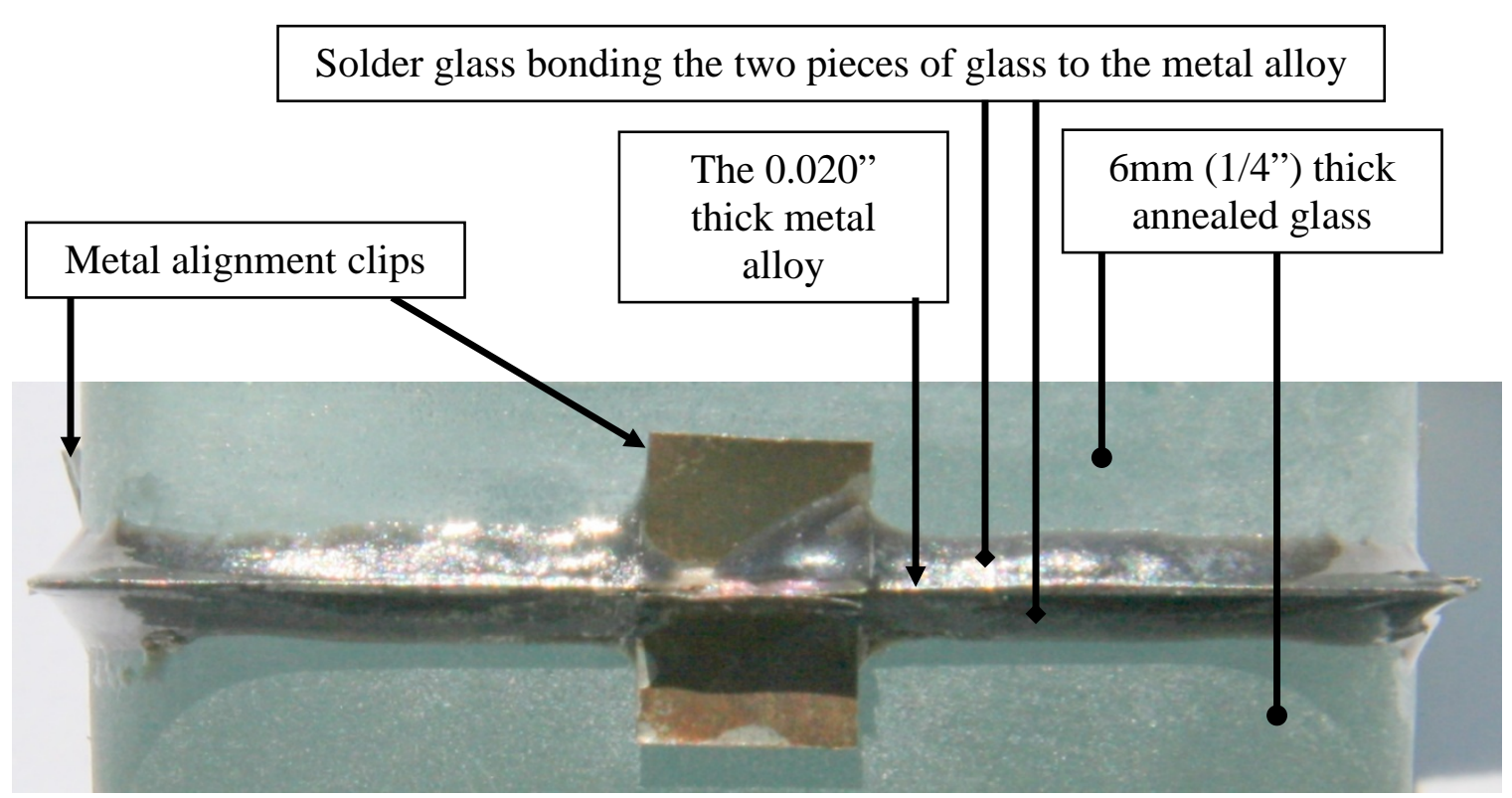

Figure 8 (above). An end-view of a TV-2 part. 


\begin{tabular}{|c|c|}
\hline \multicolumn{2}{|c|}{ Figure 9 (below): Photos of the one of the eight (8) TV-2 parts that were } \\
subjected to 250 thermal cycles and helium leak tests. \\
\hline \multicolumn{2}{|c|}{ Left Photo: } \\
$\begin{array}{c}\text { Right Photo: } \\
\text { The top side of one of the eight (8) } \\
\text { TV-2 parts. }\end{array}$ & $\begin{array}{c}\text { The bottom side of one of the eight (8) } \\
\text { TV-2 parts. }\end{array}$ \\
\hline
\end{tabular}
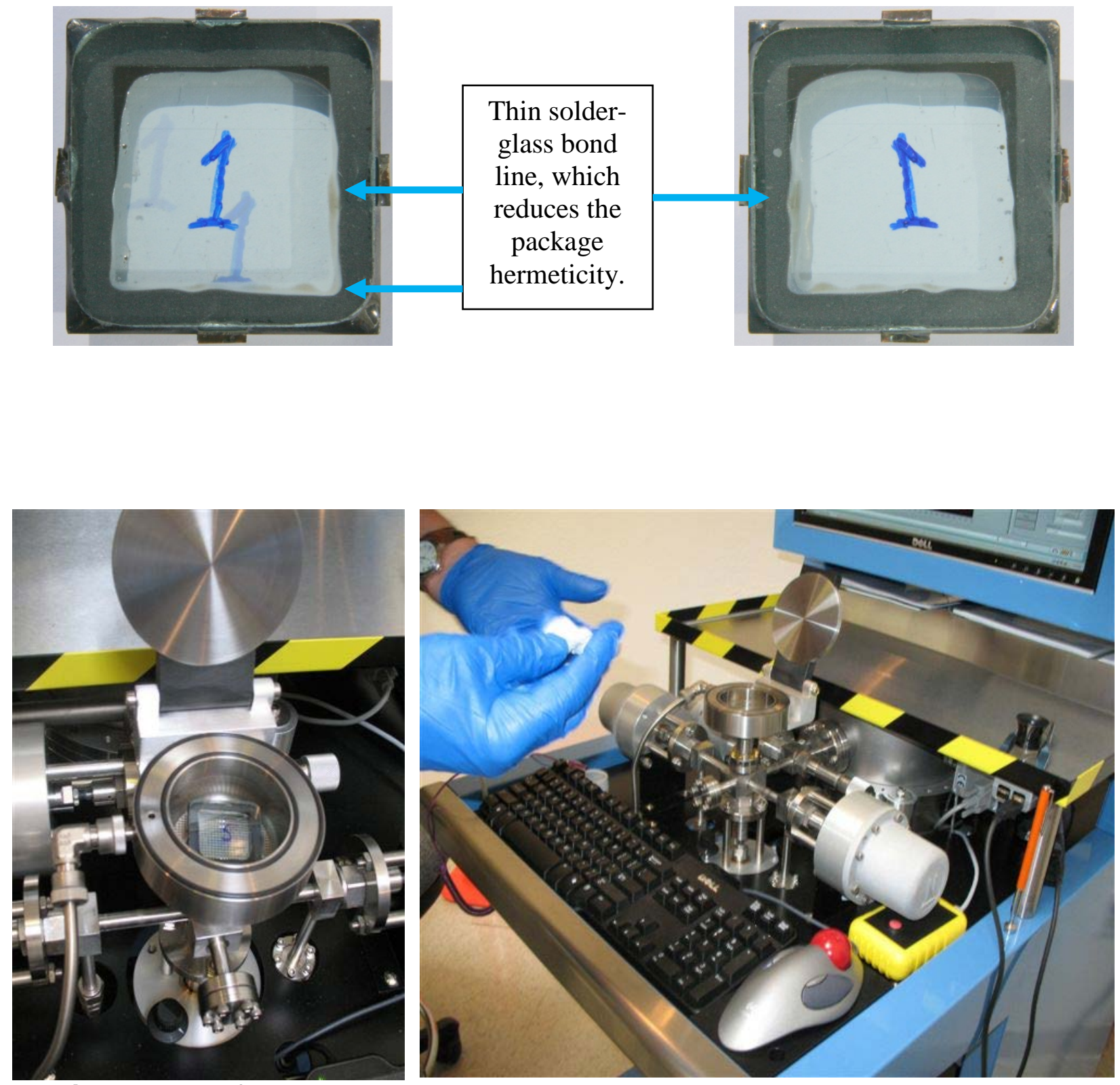

Figure 10. Left: A single window inside the sample chamber. The lid on the chamber is closed, and the chamber is evacuated for the measurement. Right: A view of the sample chamber's connection to vacuum, pressure gauges, and the mass spectrometer (located behind the chamber, obscured by the computer monitor). The entire process is run by software. 
In order to correct for the effects of permeation of helium through the glass, the permeation rate of helium was measured for the glass itself. (Figure 11) Glass permeability was measured as follows:

1. A glass sample is affixed to a first vacuum system that runs to the mass spectrometer. A second vacuum is also applied around the circumference of the first vacuum, so that any air that leaks from the edge of the seal will be removed, and will not contaminate the measurement.

2. Helium at $1 \mathrm{~atm}$ pressure is applied to the top of the glass.

3. The mass spectrometer continuously measures the helium signal over several hours. The signal for helium slowly increases as the helium gradually saturates the glass and begins to permeate through the glass. A helium leak rate is recorded after the mass spectrum signal has stabilized, indicating a constant flux of helium through the glass.

4. $3 \mathrm{~mm}$ thick and $6 \mathrm{~mm}$ thick annealed float glass were measured in this way, and the helium permeability values per $\mathrm{mm}$ thickness agreed within $10 \%$.

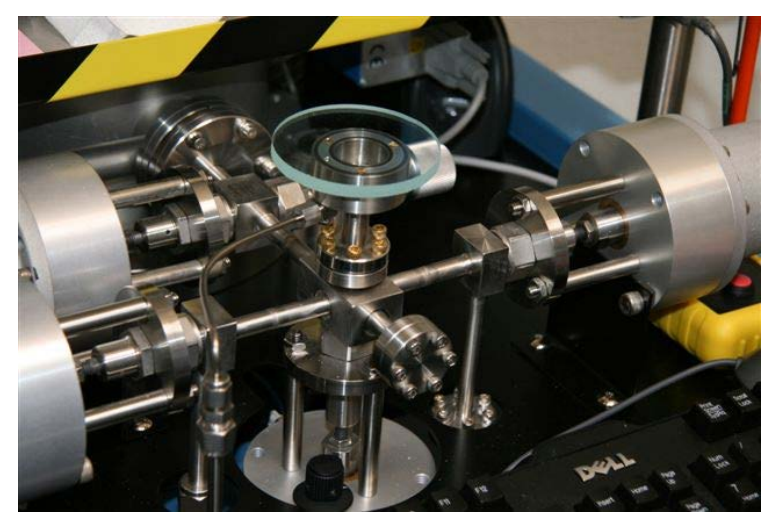

Figure 11a. For the helium test, a piece of glass is placed over the input to the mass spectrometer.

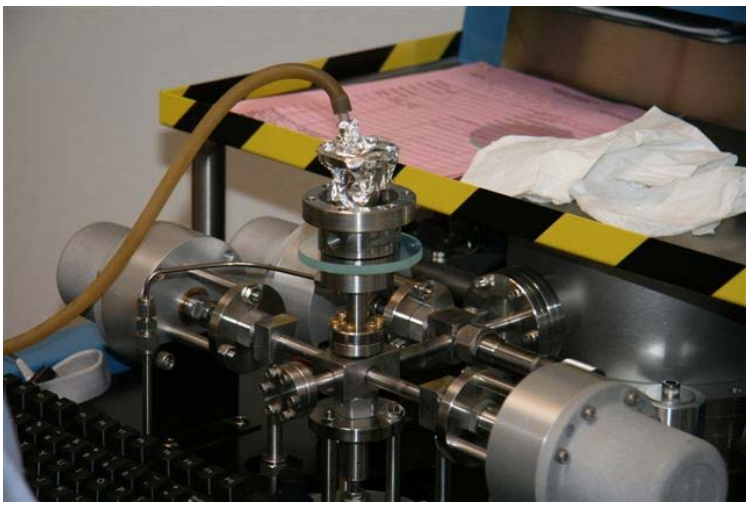

Figure 11b. The glass is jacketed with pure helium at $1 \mathrm{~atm}$, and the helium leak rate is measured after it stabilizes (several hours). 


\subsubsection{Hermeticity Test Results for the TV-2 Parts}

\subsubsection{Helium Permeability Through Glass}

Two samples of glass were used, at $3 \mathrm{~mm}$ and $6 \mathrm{~mm}$ thick, and leak rate measurements were conducted as described above for each sample. These leak rates were converted to permeation rates using the known geometry of the sample, and averaged $3.3 \times 10^{-13}(\mathrm{cc}[\mathrm{STP}] \mathrm{cm}) /\left(\mathrm{s} \mathrm{cm}^{2}\right)$ at one atmosphere pressure.

At this low leak rate, the permeation of helium through the glass into the evacuated window cavity will be negligible during the bombing process, which takes place at 4 atmospheres pressure for 24 hours. Similarly, there will be negligible permeability of helium back through the glass windows from the window interior, so this mechanism is not expected to contribute to the total leak rate.

\subsubsection{Gross Leak test}

Helium concentrations were below the gross leak threshold for all parts tested.

\subsubsection{Fine Leak test}

The fine leak rates for the 8 parts are plotted in Figure 12 on the next page: 


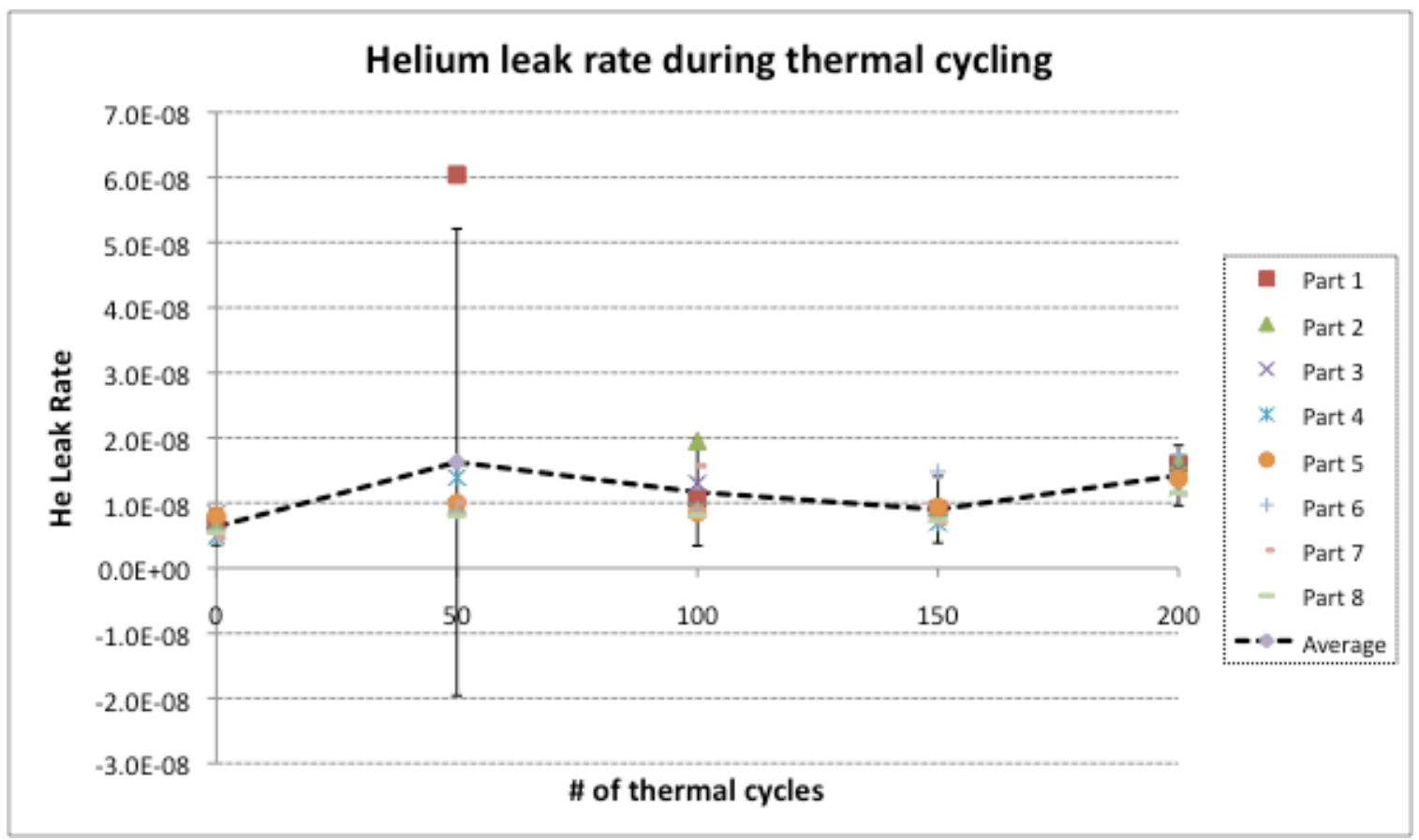

Figure 12. The average leak rates for 8 parts are plotted over the course of 250 thermal cycles. Error bars represent 2-sigma standard deviation from the average for each data point. The fine leak rate of the collection of parts was largely stable over time, within error. There was clearly one outlier at 50 thermal cycles; that part was well-behaved for the rest of the test. This difference in its leak rate occurred because this particular part was accidently left in the leak-test cell when the other seven parts were subjected to the first 50 thermal cycles; i.e., it was not re-pressurized in 4 atmospheres of pressurize He for the next leak test as was done with the other 7 parts.

A single control part (not shown) was tested twice without any thermal cycling, to assess the variability of the measurements. This part showed a $20 \%$ increase in leak rate on retest. This single-part variability is comparable with the 2 sigma error bars above, which range from $30-70 \%$ (with the exception of the single, accidental outlier at 50 thermal cycles).

Plotting the average leak rates for the parts over time, it is evident that:

1. With the exception of a single read point at 50 thermal cycles, the parts were well-behaved and clustered very tightly.

2. With the exception of the one data point for part \#1, there is, within error, essentially no change in leak rate over thermal cycling. There may be a slight uptick in leak rate after the initial read point, but more data is needed before a conclusion can be made that this is significant.

3. The leak rate of the solder glass bond line is sufficiently low enough that a vacuum insulating glass unit (VIGU) with an initial internal pressure of $10^{-4}$ torr or lower would not degrade to a pressure above the $10^{-3}$ torr cavity 
pressure necessary to have an appropriately low thermal conductivity between glass lites one and two for the desired VIGU lifetime of 40 years.

Note that the measured leak rates, while low, are not zero. This may be the result of helium permeation through the bond line, helium adsorption on the part surface, or helium trapped in the bond line itself. Further testing will be performed to quantify the contribution of these different sources of He in the leak test.

\subsubsection{Summary of Hermeticity Test Results}

ESW concluded for the TV-2 hermeticity trials that the 8 sealed parts tested are stable through 250 thermal cycles. There was no evidence of bond degradation using helium leak inspection, and the solidity of the bond line was confirmed by optical inspection. The solder-glass bond sealing technique appears to hold great promise for long-term (40+ years) stability.

\section{Cost Status for BP2}

\subsection{Budget Period 2 Cost Status (\$'s)}

\begin{tabular}{|l|r|r|r|}
\hline \multicolumn{1}{|c|}{ Description } & $\begin{array}{c}\text { Approved } \\
\text { Budget for BP2 }\end{array}$ & $\begin{array}{c}\text { Final Submittal } \\
\text { to VIPERS } \\
\text { (DOE ORNL) on } \\
\text { Nov. 17, 2006 }\end{array}$ & $\begin{array}{c}\text { Remaining } \\
\text { (Unspent) at the } \\
\text { Completion of } \\
\text { BP2 }\end{array}$ \\
\hline DOE Share & $668,663.00$ & $668,662.55$ & 0.45 \\
\hline Recipient Share & $166,444.00$ & $166,443.91$ & 0.09 \\
\hline Totals & $\mathbf{8 3 5 , 1 0 7 . 0 0}$ & $\mathbf{8 3 5 , 1 0 6 . 4 6}$ & 0.54 \\
\hline
\end{tabular}

\section{Actual or Anticipated Problems or Delays}

\subsection{Use of Stainless Steel Metals and Their Unacceptable CTE Mis-Match To Soda-Lime Float Glass}

When EverSealed Windows (ESW) planned the activities for this Project, ESW believed diffusion bonding would be used to join soda-lime float glass to a closely-matched CTE metal material. It was not anticipated that although the stainless steels chosen by members of ESW's team of engineers and scientists 
had a CTE match to glass within $1 \mathrm{ppm} /$ degree $C$ that this very small mis-match would prove to be too great and cause stress fractures in the bonded glass.

\subsection{Conversion to a Non-Stainless Steel Metal Alloy}

ESW spent over two years trying various methods to reduce the residual stress in the bond region to a reliable level, but could not do so with any of the stainless steel materials that had a close CTE match to the glass. Eventually, ESW initiated bonding trials with a specialty metal alloy that not previously been considered because of its much higher cost per pound of material. In September 2009, ESW was able to fusion bond this newly-selected metal alloy to soda-lime glass and have the bonds survive post-boning cool-down to ambient as well as several thermal cycles from -20 degrees $C$ to +100 degrees $C$ and back to -20 degrees. ESW then attempted to scale up the production of these test parts in a larger furnace using both fusion bonding and diffusion bonding. It was found that none of the dozens of parts produced by either method had strongly-adhesive bonds.

\subsection{Conversion to a Solder-Glass Bond}

Subsequent to the attempts at fusing and diffusion bonding of the specialty-metal parts to glass, ESW embarked on using its solder glass for bonding. This interlayer, along with a different metal oxidation regime, proved successful in producing robust, hermetic bonds described above in Sections 9 and 10.

\section{Product Produced or Technology Transfer Activities Accomplished During this BP2 Reporting Period}

EverSealed Windows demonstrated in BP2 that it could produce strong, hermetic glass-to-metal alloy bonds using solder glass as the bond interface. The bonds proved to be strong enough to survive calculated maximum shear stress levels at the corners of the glass-to-ESW bellows at the corners of 2' by 3' VIGUs with lite 1 at 100 degrees $C$ and lite 2 at an ambient 20 degrees $C$ (a temperature delta of 80 degrees). Thermal cycling the bonded TV-1 parts increased the shear strength of the bond by roughly 30 percent. The hermeticity tests of TV-2 parts with and without 250 thermal cycles from -30 degrees $C$ to +60 degrees $C$ showed no degradation in hermeticity and that the bonds can maintain a vacuum of at least the necessary $10^{-3}$ torr in the VIGU's cavity for minimum requirement of 40 years over the tested thermal cycling regime.

\section{Recommended Next Steps}

\subsection{A Demonstration VIGU}


ESW believes it successfully completed the DOE Grant's BP1 and BP2 deliverables and should proceed to BP3. BP3's deliverable is a working VIGU with a non-production stand-off system such as Delrin ${ }^{\mathrm{TM}}$ stand-offs. The standoff system was proposed to be a "non-production" system in the contract's WBS due to the high initial cost to develop a production-compatible, consumeracceptable stand-off system.

\subsection{A Lead-Free Solder Glass Material}

The solder glass material used for TV-1 and TV-2 parts contained lead to suppress or lower its melting temperature. The low melting temperature made it suitable for use with tempered soda-lime float glass in that it would not change the stress pattern in the tempered glass. ESW recognizes that its leadcontaining material's use would not be allowed in the European Union today for environmental law reasons and eventually also would be prohibited in the U.S. Therefore, ESW recognizes the need to create a lead-free solder glass material that has a maximum processing temperature below the 520 degrees $C$ annealing temperature of soda-lime float glass. ESW is confident that its glass and materials scientists can develop a solder glass that is lead free as well as free of other materials considered toxic for the intended VIGU application and eventual end-of-life disposal. 